TRANSPORTATION SYSTEM CONCEPT OF OPERATIONS

$D O E / R W-0584$

Revision 0 
Preparation:

Dor Nancy Slater -Thompson unific 4/3/06 Operations Project Director

Date

Review and Approval:

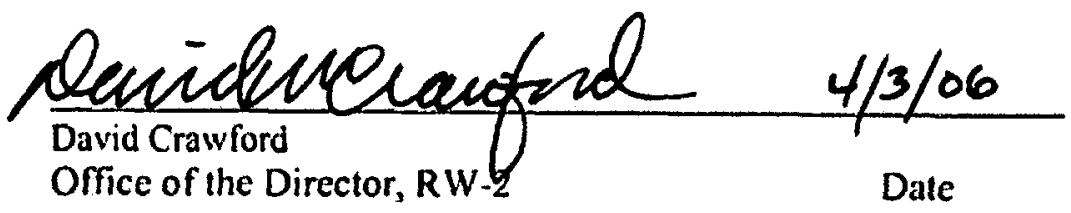

Concurrence and Approval:

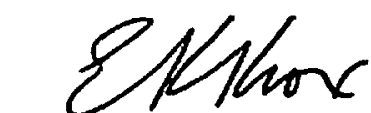

Eric Knox

Associate Director for System Operations and External Relations Office of the Director, RW-2

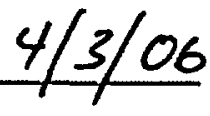

Date

Page 2 of 56 


\section{Change History}

$\begin{array}{llll}\begin{array}{l}\text { Revision } \\ \text { Number }\end{array} & \begin{array}{l}\text { Interim } \\ \text { Change No. }\end{array} & \begin{array}{l}\text { Effective } \\ \text { Date }\end{array} & \text { Description of Change } \\ 0 & 0 & 04 / 03 / 2006 & \text { Initial issue }\end{array}$


INTENTIONALLY LEFT BLANK

Page 4 of 56 


\section{Table of Contents}

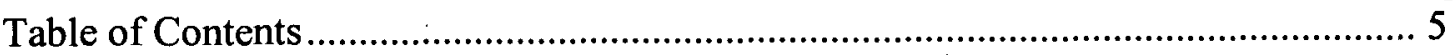

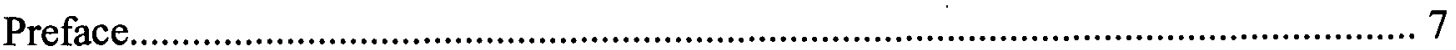

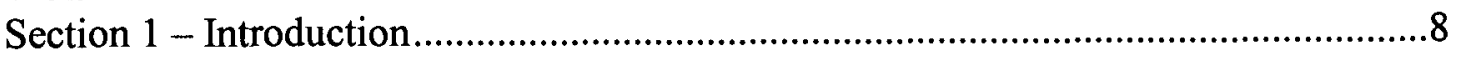

Section 2 - Need for the OCRWM Transportation System ..................................... 10

Section 3 - Vision for the OCRWM Transportation System ....................................11

Section 4 - Mission and Scope of the OCRWM Transportation System .................... 12

Section 5 - Technical Baseline for Transportation System Operations ......................17

Section 6 - Parties Interested in the Transportation System...................................... 19

Section 7 - Transportation System Customers, Project Directors, and Service Providers.......................................................20

Section 8 - Description of the Transportation System Major Operational Stages ......22

Stage 1 - Shipment Planning and Management ....................................23

Stage 2 - Assembly and Dispatch from the FMF .................................24

Stage 3 - Delivery to Origin Site ......................................................25

Stage 4 - Cask Handling and Loading at Origin Site ............................26

Stage 5 - Transporting Loaded Casks to the Repository........................27

Stage 6 - Retrieving Unloaded Casks from the Repository ....................28

Stage 7 - Return of Rolling Stock and Auxiliary Equipment..................28

Stage 8 - Reassembly and Preparation for Shipment ............................29

Section 9 - OCRWM Transportation System Support Environment ..........................34

Transportation Operations Center.......................................................34

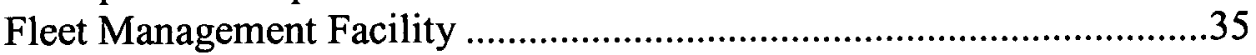

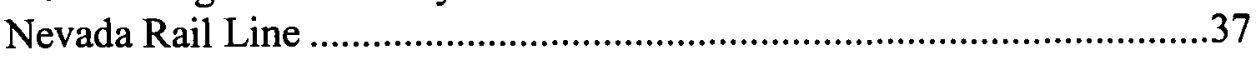

Caliente Interchange Rail Yard......................................................38

End of Line Rail Yard....................................................................40

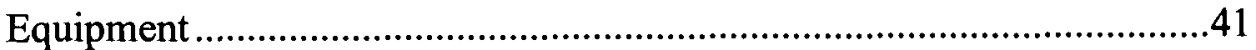

Communications System ...........................................................42

Section 10 - Transportation System Operations Scenarios ......................................43

Routine Operations Scenarios.........................................................43

Emergency Operations Scenarios .....................................................49

\section{Table of Figures}

Figure 4-1 - Mission and Scope of the Transportation System.................................12

Figure 5-1 - Transportation System Documents .................................................17

Figure 8-1 - Closed Loop Transportation System................................................22

Figure 8-2 - Transportation System Process Flow ............................................30

Figure 10-1 - Direct Rail Shipment................................................................44

Figure 10-2 - Rail Shipment via Marshaling Yard...............................................45

Figure 10-3 - Rail Shipment via Inter-Modal Transfer ..........................................46

Figure 10-4 - Rail Shipment via Marshaling Yard and IMT ...................................47

Figure 10-5 - Direct Truck Shipment ...................................................................48 


\section{Table of Tables}

Table 4-1 - Transportation System Interfaces and Elements ...............................13

Table 8-1 - Transportation System Operational Stages ...........................................31

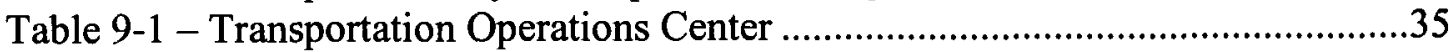

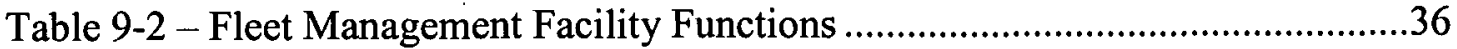

Table 9-3 - Nevada Rail Line Functions ..............................................................38

Table 9-4 - Caliente Interchange Rail Yard Functions ............................................39

Table 9-5 - End of Line Rail Yard Functions ....................................................40

Table 9-6 - Transportation System Transporter Types ............................................41

Table 9-7 - Casks and Associated Equipment..........................................................42

\section{Appendices}

Appendix A - Transportation System References .................................................51

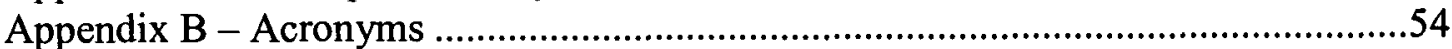




\section{Preface}

The Transportation System Concept of Operations is a document prepared by the Department of Energy (DOE) Office of Civilian Radioactive Waste Management (OCRWM), which describes the Transportation System, which is one element of the total Civilian Radioactive Waste Management System (CRWMS). A safe, dependable Transportation System is a necessary component to the operation of the national nuclear waste Repository at Yucca Mountain in Nevada. This document provides the conceptual foundation for effective transportation development and operations and presents an overview of the range of functions, activities, processes, assets, and interfaces that constitute a fully operational Transportation System.

As the cornerstone System Description Document (SDD) for OCRWM transportation, the Transportation System Concept of Operations serves as the starting point for its structured systems engineering process. This system's engineering process will establish the detailed requirements, procedures, and operational practices needed to implement the complex multi-modal Transportation System to ship spent nuclear fuel (SNF) and high-level radioactive waste (HLW) from origin sites to the Repository.

The Transportation System Concept of Operations is the high-level description of Transportation System design, and it defines the fundamental operational elements of the Transportation System. Simply stated, the Transportation System Concept of Operations, at a minimum, identifies the Transportation System:

- Vision, mission, and scope;

- Stakeholders;

- High-level capabilities;

- Geographical and physical features;

- Functions and activities;

- Operational processes and interfaces; and

- Support environment.

By articulating the operational goals of the Transportation System, the Transportation System Concept of Operations promotes common understanding among customers, project directors, operators, and policymakers working together in the pursuit of safe, secure transportation and disposal of the nation's SNF and HLW. 


\section{Section 1}

\section{Introduction}

The Nuclear Waste Policy Act of 1982 (NWPA), as amended, authorized the DOE to develop and manage a Federal system for the disposal of SNF and HLW. OCRWM was created to manage acceptance and disposal of SNF and HLW in a manner that protects public health, safety, and the environment; enhances national and energy security; and merits public confidence. This responsibility includes managing the transportation of SNF and HLW from origin sites to the Repository for disposal.

The Transportation System Concept of Operations is the core high-level OCRWM document written to describe the Transportation System integrated design and present the vision, mission, and goals for Transportation System operations. By defining the functions, processes, and critical interfaces of this system early in the system development phase, programmatic risks are minimized, system costs are contained, and system operations are better managed, safer, and more secure.

This document also facilitates discussions and understanding among parties responsible for the design, development, and operation of the Transportation System. Such understanding is important for the timely development of system requirements and identification of system interfaces. Information provided in the Transportation System Concept of Operations includes: the functions and key components of the Transportation System; system component interactions; flows of information within the system; the general operating sequences; and the internal and external factors affecting transportation operations.

The Transportation System Concept of Operations reflects OCRWM's overall waste management system policies and mission objectives, and as such provides a description of the preferred state of system operation. The description of general Transportation System operating functions in the Transportation System Concept of Operations is the first step in the OCRWM systems engineering process, establishing the starting point for the lower level descriptions of subsystems and components, and the Transportation System Requirements Document. Other program and system documents, plans, instructions, and detailed designs will be consistent with and informed by the Transportation System Concept of Operations.

The Transportation System Concept of Operations is a living document, enduring throughout the OCRWM systems engineering lifecycle. It will undergo formal approval and controlled revisions as appropriate while the Transportation System matures. Revisions will take into account new policy decisions, new information available through system modeling, engineering investigations, technical analyses and tests, and the introduction of new technologies that can demonstrably improve system performance. 
The Transportation System Concept of Operations is generally consistent with the American National Standards Institute and the American Institute of Aeronautics and Astronautics (ANSI/AIAA) G-043-1992: Guide for the Preparation of Operational Concept Documents, and contains ten sections and two appendices, as well as figures and tables, which supplement narrative discussions:

- Section 1 contains the Introduction.

- Section 2 explains the Need for the Transportation System.

- Section 3 describes the Transportation System Vision.

- Section 4 explains the Transportation System Mission and Scope.

- Section 5 summarizes the Transportation System Operations Technical Baseline.

- Section 6 identifies Parties Interested in the Transportation System.

- Section 7 identifies the Transportation System Customers, Project Directors, and Service Providers.

- Section 8 describes the Eight Major Operational Stages of the Transportation System.

- Section 9 discusses the Transportation System Support Environment.

- Section 10 provides Transportation System Operations Scenarios.

- Appendix A provides a supplemental table of Transportation System References.

- Appendix B provides a list of Acronyms. 


\section{Section 2}

\section{Need for the OCRWM Transportation System}

Currently, there are thousands of tons of SNF and HLW stored at numerous sites throughout the Nation. These materials could pose a risk to the health and safety of future generations, if not properly managed. To protect the public and the environment, the Federal government will dispose of SNF and HLW at the Repository. Figure 2-1, SNF and HLW Origin Sites, depicts the approximate locations of current commercial and DOE origin sites and the Repository.

\section{Figure 2-1 SNF and HLW Origin Sites}

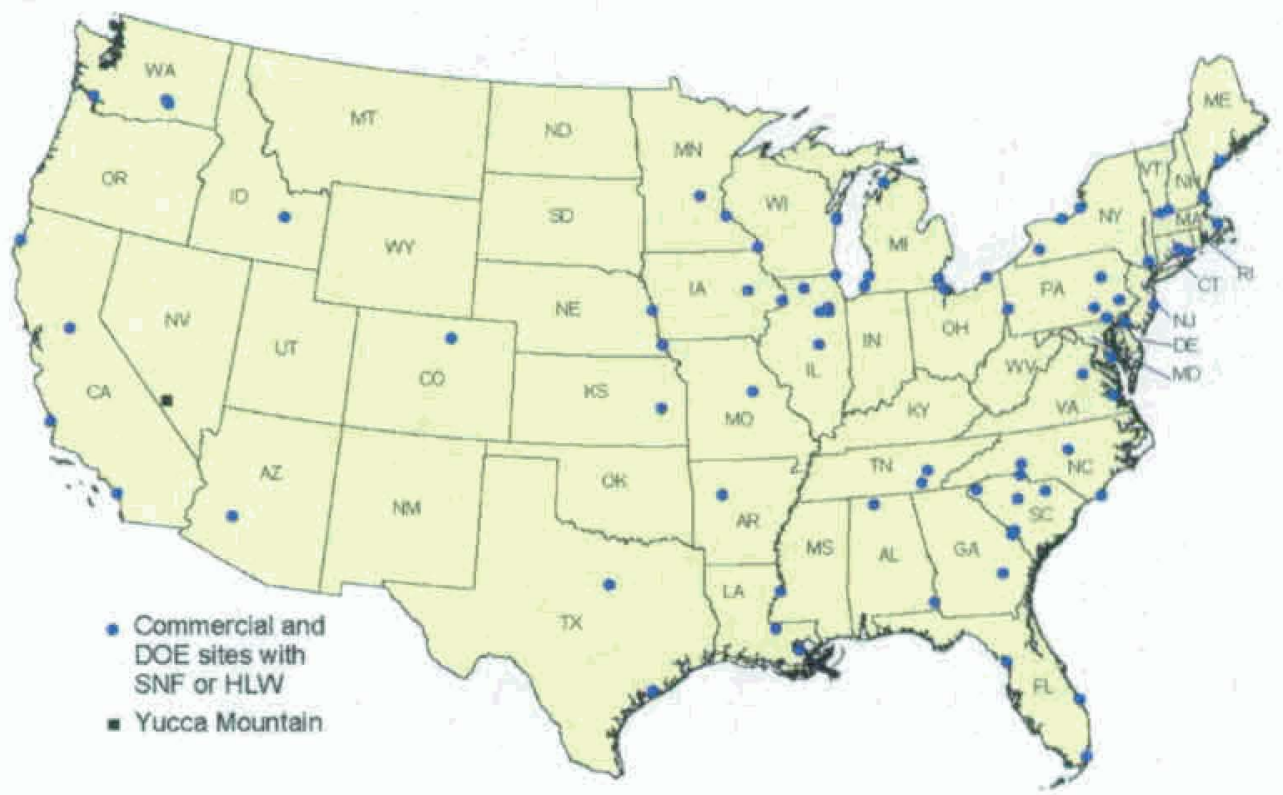

OCRWM is developing a safe, secure Transportation System that will be ready to ship SNF and HLW to the Repository from origin sites throughout the Nation and that:

- Is based on the 50-year long worldwide history of successful, safe, and secure shipping practices employed by commercial and government organizations to transport SNF;

- Incorporates long-range logistics planning;

- Relies mostly on rail, and includes some truck and barge shipments;

- Includes facilities, procurement of services and specialized equipment, and training of operations, safety, security, and emergency response personnel; and

- Involves State and Tribal governments in planning and preparing for shipments through their jurisdictions. 


\section{Section 3}

\section{Vision for the OCRWM Transportation System}

The OCRWM Transportation System will safely, securely, and effectively transport SNF and HLW to the Geologic Repository Operating Area (GROA) at Yucca Mountain. Intrinsic to its design is the clear articulation of the criteria and methodology for making operational decisions. The criteria and methodology support a flexible and adaptable system that can respond to changing requirements, infrastructure, and resources without compromising safety, security, or effectiveness.

The Transportation System will:

- Acquire and maintain transportation infrastructure;

- Maximize the use of commercial providers to transport and perform operational services, to the extent possible;

- Use commercial or government off-the-shelf technologies with proven success as appropriate;

- Establish partnerships with other DOE offices and Federal agencies to gain access to expertise and resources that may improve safety, security, operating standards, or realize efficiencies in Transportation System costs, schedules, processes, and acquisitions;

- Partner and communicate with State, local, and Tribal authorities representing jurisdictions and communities through which nuclear waste shipments are transported; and

- Integrate its operations with other OCRWM systems to assure optimal use of Transportation System assets. 


\section{Section 4}

\section{Mission and Scope of OCRWM Transportation System}

The mission of the Transportation System is to transport loaded casks of SNF and HLW safely and securely from origin sites to the Repository. The work scope supporting this mission includes shipment planning, dispatch of unloaded casks to an origin site, transport of loaded casks to the Repository, and maintenance of unloaded casks and ancillary equipment at the Fleet Management Facility (FMF).

Figure 4-1 displays the OCRWM Transportation System Mission and Scope. The Transportation System operations and facilities presented in the shaded area represent the scope of Transportation System responsibilities. The solid arrows show the process by which unloaded casks will move from the FMF to origin sites to be loaded and then transported to Yucca Mountain before being returned as unloaded casks back to the FMF. Similarly, the dashed arrows indicate the flow of information exchanged between the Transportation Operations Center and the origin sites, the FMF, and Yucca Mountain. Loading casks prior to transport to the Yucca Mountain Repository is a site responsibility.

Figure 4-1 Mission and Scope of the Transportation System

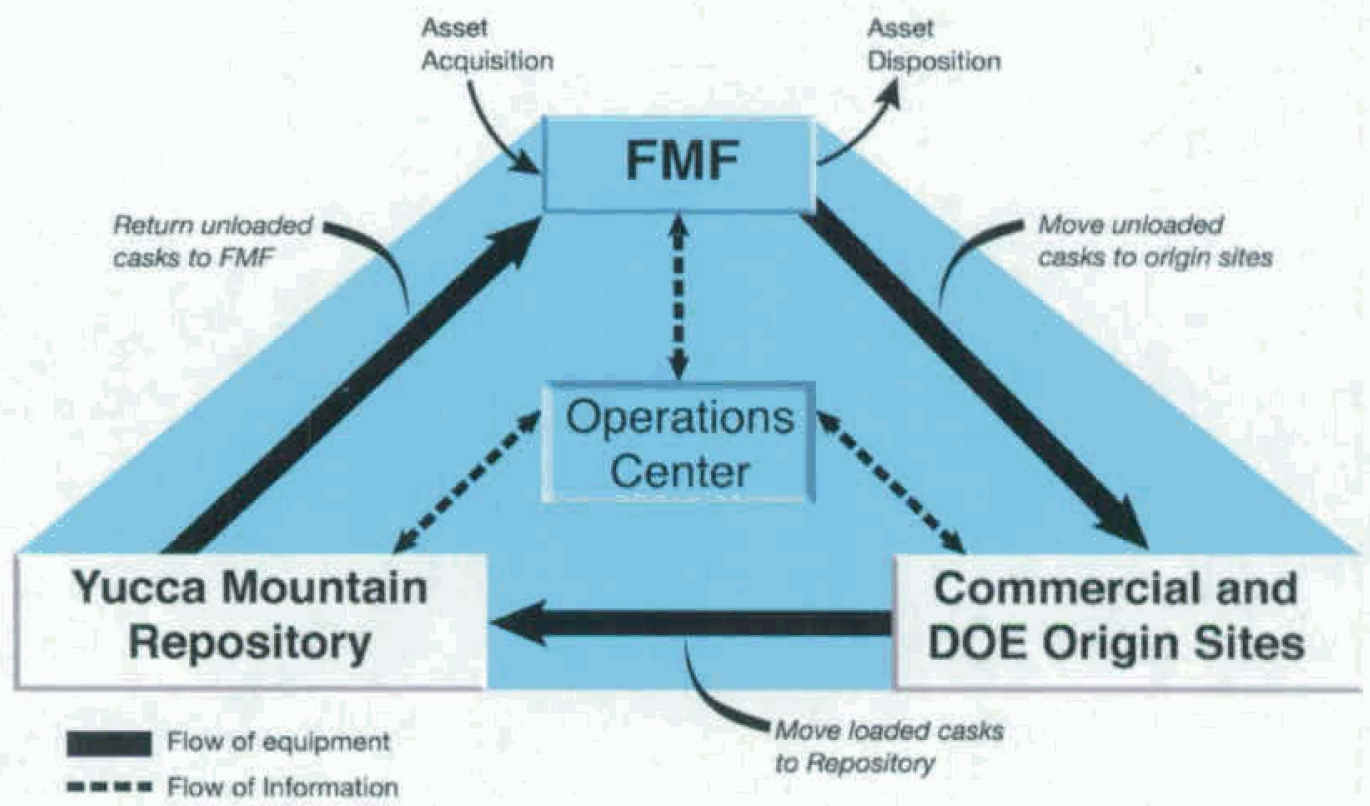

Beginning on the following page, Table 4-1 describes major Transportation System interfaces and elements. 


\section{Table 4-1 TRANSPORTATION SYSTEM INTERFACES AND ELEMENTS}

\begin{tabular}{|c|c|}
\hline \multicolumn{2}{|r|}{ Transportation System Interfaces } \\
\hline Origin & $\begin{array}{l}\text { Commercial and DOE sites are the "origin" or starting point of SNF and HLW } \\
\text { shipments. Some origin sites have rail service, while others do not. The latter } \\
\text { require alternative inter-modal delivery from the origin site to a nearby rail transfer } \\
\text { or barge location in order to load rail casks. At some sites with limited cask } \\
\text { handling capability, trucks will be used to deliver and pick up smaller casks. }\end{array}$ \\
\hline Destination & $\begin{array}{l}\text { The destination for delivery of SNF and HLW is the monitored Geologic } \\
\text { Repository Operations Area (GROA) at Yucca Mountain (YM). Since YM has no } \\
\text { current rail service, DOE has proposed construction and operation of a Nevada Rail } \\
\text { Line (NRL) between Caliente, NV, and YM. }\end{array}$ \\
\hline \multicolumn{2}{|r|}{ Materials Shipped by the OCRWM Transportation System } \\
\hline $\begin{array}{c}\text { Spent Nuclear } \\
\text { Fuel (SNF) }\end{array}$ & $\begin{array}{l}\text { "The term 'spent nuclear fuel' means fuel that has been withdrawn from a nuclear } \\
\text { reactor following irradiation, the constituent elements of which have not been } \\
\text { separated by reprocessing." }\end{array}$ \\
\hline $\begin{array}{l}\text { High-Level } \\
\text { Radioactive } \\
\text { Waste (HLW) }\end{array}$ & $\begin{array}{l}\text { "The term 'high-level radioactive waste' means (a) the highly radioactive material } \\
\text { resulting from the reprocessing of spent nuclear fuel, including liquid waste } \\
\text { produced directly in reprocessing and any solid material derived from such liquid } \\
\text { waste that contains fission products in sufficient concentrations; or (b) other highly } \\
\text { radioactive material that the Nuclear Regulatory Commission (NRC), consistent } \\
\text { with existing law, determines by rule to require permanent isolation." }\end{array}$ \\
\hline \multicolumn{2}{|r|}{ Transportation Services } \\
\hline Rail & $\begin{array}{l}\text { Rail Service: Most commercial and Federal nuclear sites can be accessed by rail } \\
\text { either by short-line railroads or by Class } 1 \text { (main-line) railroads. There are } \\
\text { numerous short-line railroads that operate one or more relatively small sections of } \\
\text { track connecting to the Class } 1 \text { rail networks. The Union Pacific (UP) Railroad } \\
\text { serves NRL, transferring at the Caliente Interchange Rail Yard. Most shipments } \\
\text { are likely to travel over more than one railroad (interlining carriers) with } \\
\text { interchanges between the railroads occurring only at designated rail yards. DOE } \\
\text { will use dedicated train (i.e., rail service dedicated to one commodity, enabling } \\
\text { shipments to bypass classification yards) for its usual rail transport of SNF and } \\
\text { HLW to the YM when the Repository is operational. } \\
\text { Rail Consist: The typical rail consist includes: a locomotive, a security escort car, } \\
\text { and one or more loaded cask rail cars separated from the locomotive and security } \\
\text { escort cars by buffer rail cars. The security escort car is occupied by the } \\
\text { Transportation Security Force (TSF) accompanying each shipment. The TSF } \\
\text { maintains continuous visual contact with the casks and communicates shipment } \\
\text { progress to Transportation Operations Center personnel. }\end{array}$ \\
\hline Truck & $\begin{array}{l}\text { Truck Service: At origin sites without the capacity to handle rail casks, a } \\
\text { conventional highway truck is used to deliver one small-capacity cask. After } \\
\text { loading and preparation, the cask is picked up and delivered directly to the }\end{array}$ \\
\hline
\end{tabular}




\begin{tabular}{|c|c|}
\hline & $\begin{array}{l}\text { Repository using the public highway network, or in some cases, is loaded onto a } \\
\text { rail car at an inter-modal transfer (IMT) site. } \\
\text { Truck Convoy: A truck convoy includes the cask trailer, a transport tractor (semi- } \\
\text { truck cab), and a shipment security escort vehicle. Multiple truck shipments to or } \\
\text { from a single origin site may be arranged as a convoy or sequentially to improve } \\
\text { shipment schedules. Similar to rail shipments, the TSF accompanying a truck } \\
\text { shipment maintains continuous surveillance of casks and communicates shipment } \\
\text { progress to Transportation Operations Center personnel. }\end{array}$ \\
\hline $\begin{array}{c}\text { Heavy Haul } \\
\text { Truck (HHT) }\end{array}$ & $\begin{array}{l}\text { At origin sites lacking direct rail service, casks can be delivered by rail to a nearby } \\
\text { IMT site, then removed and placed on a specialized heavy-haul truck (HHT) for } \\
\text { transport to and from the origin site via local highways. Once casks are loaded, } \\
\text { they return to the same IMT site via HHT, transfer to rail cars, and then are } \\
\text { transported to Yucca Mountain. The TSF accompanying HHT shipments maintain } \\
\text { continuous surveillance of casks and communicate shipment progress to } \\
\text { Transportation Operations Center personnel. }\end{array}$ \\
\hline Barge & $\begin{array}{l}\text { At origin sites, which lack direct rail service and can be accessed by barge, a HHT } \\
\text { (depending on the cask handling capacity of the origin site) moves casks from the } \\
\text { rail IMT site to a dock where the HHT with a cask is transferred to a barge. The } \\
\text { barge is delivered to a dock at a location near the origin site and an HHT delivers } \\
\text { the cask for loading to the origin site. After loading the cask, the reverse process is } \\
\text { used to return the loaded cask from the origin site to the rail IMT site. As with all } \\
\text { other shipments, the TSF will provide security for the barge portion of a shipment, } \\
\text { in coordination with the U.S.'Coast Guard (USCG) and States. }\end{array}$ \\
\hline \multicolumn{2}{|r|}{ Transportation Equipment } \\
\hline Casks & $\begin{array}{l}\text { DOE procures only casks that are NRC certified to contain radioactive contents } \\
\text { under severe transportation accident conditions. Origin sites may also procure } \\
\text { some casks. Casks, varying in size from about } 20 \text { tons gross weight up to } \\
\text { approximately } 125 \text { tons gross weight, are acquired. DOE estimates that } \\
\text { approximately } 130 \text { to } 150 \text { reusable transport casks will be needed. The final mix of } \\
\text { casks in the cask fleet is determined according to origin site capabilities, SNF and } \\
\text { HLW inventories, Repository throughput capacity, and Final Delivery Schedules } \\
\text { (FDS). }\end{array}$ \\
\hline Canister & $\begin{array}{l}\text { Canister is the structure surrounding the waste form (e.g., HLW immobilized in } \\
\text { borosilicate glass) that facilitates handling, storage, transportation, and/or disposal. } \\
\text { A canister is a metal receptacle with the following purpose: (1) for solidified } \\
\text { HLW, its purpose is a pour mold; and (2) for SNF, it may provide structural } \\
\text { support for intact SNF, loose rods, non-fuel components, or confinement of } \\
\text { radionuclides. } \\
\text { The Transport Aging Disposal (TAD) canister is a component of the radioactive } \\
\text { waste management system that allows for SNF temporary storage at an origin site, } \\
\text { safe transport from the origin site to the Repository, aging at the Repository, and } \\
\text { emplacement in the Repository. A TAD canister is placed inside of the appropriate } \\
\text { cask or package depending on the stage in the transfer process of SNF from an } \\
\text { origin site for ultimate disposal at YM. In addition to the TAD canister, there are } \\
\text { storage casks, transport casks, and waste packages. }\end{array}$ \\
\hline
\end{tabular}




\begin{tabular}{|c|c|}
\hline Cask Skids & $\begin{array}{l}\text { Some casks are transported on removable inter-modal skids that allow movement } \\
\text { of casks from railcars to HHT or barges by portable cranes. Skids are designed to } \\
\text { fit on transporters and are customized to accommodate a specific cask model. }\end{array}$ \\
\hline Cask Rail Cars & $\begin{array}{l}\text { Cask rail cars are up to } 100 \text {-feet long and designed to accept a cask and skid with a } \\
\text { combined weight of up to } 200 \text { tons. }\end{array}$ \\
\hline $\begin{array}{c}\text { Cask Ancillary } \\
\text { Equipment }\end{array}$ & $\begin{array}{l}\text { Each cask design requires unique equipment for lifting, operating, and leak testing. } \\
\text { DOE purchases sufficient sets of this "ancillary equipment" to operate the cask } \\
\text { fleet. DOE also acquires sufficient spare, replacement, and consumable parts and } \\
\text { components for cask repairs to ensure a consistent supply of casks in working order } \\
\text { and maximum cask availability for shipments. }\end{array}$ \\
\hline $\begin{array}{l}\text { Rail and Truck } \\
\text { Security Escort } \\
\quad \text { Vehicles }\end{array}$ & $\begin{array}{l}\text { Each SNF or HLW shipment is accompanied by the TSF personnel assigned to } \\
\text { provide continuous physical protection. For rail shipments, DOE plans to design } \\
\text { and procure security escort cars to support and house the TSF during shipments. } \\
\text { Security escort rail cars accommodate the TSF for a week or more. For truck } \\
\text { shipments, DOE plans to use Department-approved vans or other vehicles } \\
\text { configured for use by the TSF. }\end{array}$ \\
\hline $\begin{array}{l}\text { Buffer Rail } \\
\text { Cars }\end{array}$ & $\begin{array}{l}\text { Buffer cars will be used to meet Federal hazardous materials transportation } \\
\text { regulations that require a non-placarded (buffer) rail car to separate any rail car } \\
\text { displaying a radioactive placard and any occupied rail car, including locomotives. } \\
\text { A buffer car does not interfere with TSF visual contact with cask railcars. }\end{array}$ \\
\hline Locomotives & $\begin{array}{l}\text { For cross-country shipments, DOE may request that commercial carriers provide } \\
\text { locomotives or may acquire locomotives through a purchase or lease of dedicated } \\
\text { locomotives to ensure availability of power sources for the rail shipments. On the } \\
\text { NRL, DOE may use commercial railroad or NRL dedicated locomotives for } \\
\text { shipments to and from the Caliente Interchange Rail Yard, End of Line (EOL) Rail } \\
\text { Yard outside of the Repository, and the FMF. The EOL Rail Yard and Caliente } \\
\text { Interchange Rail Yards will have switch engines or equivalent power sources to } \\
\text { enable assembly and movement of trains and consists that are needed to support } \\
\text { Transportation System operations. }\end{array}$ \\
\hline Cask trailers & $\begin{array}{l}\text { DOE uses legal weight trucks (LWT) and over weight trucks (OWT) with a gross } \\
\text { vehicle weight within Federal and State limits to move small casks. Casks } \\
\text { weighing from } 20 \text { to } 40 \text { tons gross weight can be transported by truck over public } \\
\text { roads with annual permits and minimal restrictions. Standard trailers support these } \\
\text { shipments. Truck trailers for heavy haul casks are custom-built for specific cask } \\
\text { models and may accommodate inter-modal (trailer-on-flat-car) rail shipment as } \\
\text { necessary. HHT shipments require a permit for each shipment by each State. }\end{array}$ \\
\hline Tractors & $\begin{array}{l}\text { Over the road tractors (semi-truck cabs) are used to transport cask trailers to and } \\
\text { from origin sites. Tractors are provided as part of the highway carrier services. }\end{array}$ \\
\hline $\begin{array}{c}\text { Misc. } \\
\text { Equipment }\end{array}$ & $\begin{array}{l}\text { DOE purchases miscellaneous equipment to support SNF and HLW shipments, } \\
\text { including mobile communications equipment and other necessary safety and } \\
\text { security devices. }\end{array}$ \\
\hline \multicolumn{2}{|r|}{ Transportation System Facilities } \\
\hline $\begin{array}{c}\text { Fleet } \\
\text { Management } \\
\text { Facility }(F M F)\end{array}$ & $\begin{array}{l}\text { DOE may lease or construct the FMF to maintain Transportation System } \\
\text { equipment. The DOE-regulated FMF is located outside of the GROA at a secure } \\
\text { site. FMF functions include: temporary parking and staging for rolling stock (i.e., } \\
\text { railcars, trailers, trucks, and security escort cars) and locomotives; performance of } \\
\text { routine and minor maintenance and repairs; and warehousing of ancillary and }\end{array}$ \\
\hline
\end{tabular}




\begin{tabular}{|c|c|}
\hline & $\begin{array}{l}\text { support equipment (e.g., cask lifting yokes, testing, spare parts, and associated } \\
\text { packaging equipment). Cask inspections and containment verification tests are } \\
\text { conducted at the FMF. }\end{array}$ \\
\hline $\begin{array}{c}\text { Nevada Rail } \\
\text { Line (NRL) }\end{array}$ & $\begin{array}{l}\text { The Nevada Rail Line (NRL) is the new single-line railroad estimated to be } 320 \text { to } \\
350 \text { miles long. It extends from the Union Pacific (UP) Railroad interchange at } \\
\text { Caliente to the EOL Rail Yard located just outside the GROA. The principal } \\
\text { function of the railroad is to move trains between Caliente and the Repository in } \\
\text { one rail crew work shift of approximately } 12 \text { hours. Shipments to and from the } \\
\text { Repository include trains transporting loaded and unloaded casks, as well as } \\
\text { construction supplies and Repository operations equipment. }\end{array}$ \\
\hline $\begin{array}{l}\text { Caliente } \\
\text { Interchange } \\
\text { Rail Yard }\end{array}$ & $\begin{array}{l}\text { For planning purposes, the Transportation System Concept of Operations assumes } \\
\text { that OCRWM will complete the draft Environmental Impact Statement for the } \\
\text { Alignment, Construction, and Operation of a Rail Line to a Geologic Repository at } \\
\text { Yucca Mountain, Nye County, Nevada which will recommend construction of the } \\
\text { NRL along a proposed corridor from Caliente, Nevada to the YM Repository. In } \\
\text { general, the same planning assumptions that describe the functions and capabilities } \\
\text { of the Caliente Interchange Rail Yard would apply were another rail interchange } \\
\text { selected for the NRL, and Transportation System documents would be revised } \\
\text { accordingly. } \\
\text { Based on current plans, the Caliente Interchange Rail Yard is the transfer point } \\
\text { from commercial carrier transport to DOE transport on the NRL and provides the } \\
\text { interface between UP and DOE rail operations. The Caliente Interchange Rail } \\
\text { Yard supports rail cars hauling freight, construction equipment, and loaded and } \\
\text { unloaded casks and provides equipment to support inspections in compliance with } \\
\text { DOE regulations. The Caliente Interchange Rail Yard is equipped with switches } \\
\text { and sidings to allow for the movement of rail freight between UP and the NRL. } \\
\text { Direction for Caliente Interchange Rail Yard movements is provided by the DOE } \\
\text { Caliente Interchange Rail Yard Master, in coordination with the Transportation } \\
\text { Operations Center and the NRL train center. }\end{array}$ \\
\hline $\begin{array}{l}\text { End of Line } \\
\text { (EOL) Rail } \\
\quad \text { Yard }\end{array}$ & $\begin{array}{l}\text { The End of Line (EOL) Rail Yard is situated at the NRL termination point outside } \\
\text { of the GROA. The EOL Rail Yard, which consists of rail switching stations, } \\
\text { marshaling yards, and necessary support structures, is the initial transfer point for } \\
\text { moving loaded casks to the GROA and for transferring rail cars to the FMF. After } \\
\text { train consists arrive at the EOL Rail Yard, they are decoupled, cask rail cars are } \\
\text { transported to the GROA via a separate switch engine, and buffer and security } \\
\text { escort rail cars are transported to the FMF separately. Once unloaded, casks and } \\
\text { cask rail cars are sent to the FMF via the EOL Rail Yard. Movements within the } \\
\text { EOL Rail Yard are directed by the EOL Rail Yard Master and coordinated with the } \\
\text { Transportation Operations Center. }\end{array}$ \\
\hline $\begin{array}{l}\text { Transportation } \\
\text { Operations } \\
\text { Center }\end{array}$ & $\begin{array}{l}\text { The Transportation Operations Center manages all aspects of the Transportation } \\
\text { System, including communications. The Transportation Operations Center } \\
\text { conducts core functions for shipment planning; operations management; and } \\
\text { control of system assets. Other critical functions include safety, security, } \\
\text { environmental protection, and maintenance oversight. The Transportation } \\
\text { Operations Center provides appropriate information to authorized stakeholder } \\
\text { organizations and the Public Information Office for public release. }\end{array}$ \\
\hline
\end{tabular}




\section{Section 5}

\section{Technical Baseline for Transportation System Operations}

The technical baseline for Transportation System operations consists of a structured set of documents that clearly describe the overall system elements, interfaces, and components in appropriate levels of detail. The relationship among these documents is shown in Figure 5-1, Transportation System Documents. The arrows depict the information flow from one document to another. System engineering processes used to develop the document are also indicated.

Figure 5-1 Transportation System Documents

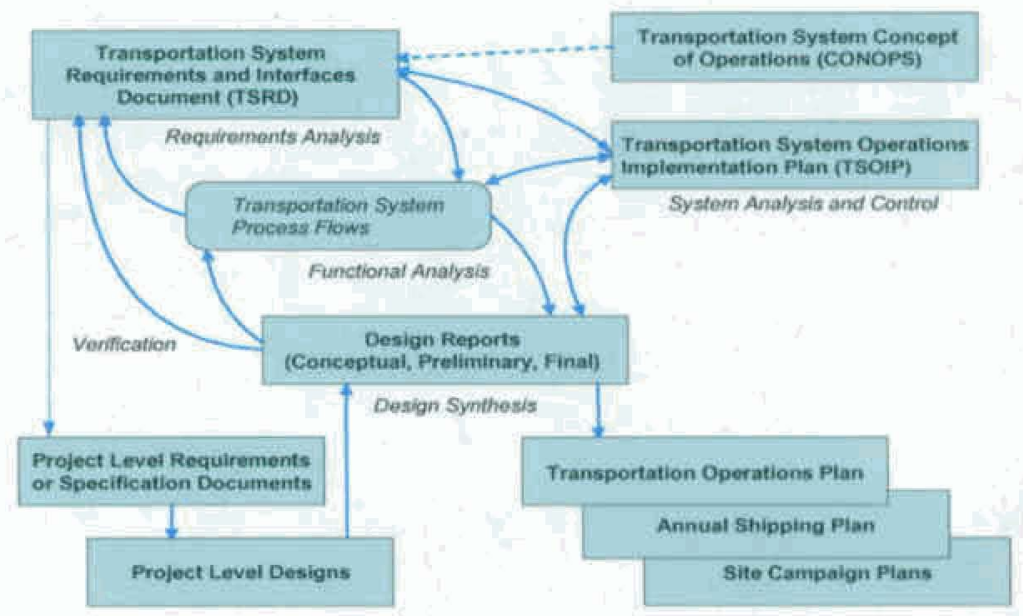

The technical baseline includes the Transportation System Concept of Operations, which is the high-level description of Transportation System design and operations. Although the Transportation System Concept of Operations is not a requirements document, it is a principal source of information for the development of system performance requirements, which are contained in the Transportation System Requirements Document.

The Transportation System Requirements Document (TSRD) is derived from numerous sources and identifies the first level of Transportation System requirements and interfaces. These sources include legal, regulatory, and policy, and higher-level OCRWM requirements documents such as the Civilian Radioactive Waste Management System Requirements Document (CRD). The Transportation System Concept of Operations and the requirements analysis process add further clarity to the TSRD. Rather than creating a separate document for the identification and control of interfaces within the Transportation System, the TSRD identifies the internal interfaces for the components of the Transportation System. In so doing, operational processes are fully integrated and functional responsibilities are clearly defined. 
The interfaces defined in the TSRD are consistent with OCRWM's Integrated Interface Control Document, Volumes 1. As the Transportation System matures and the Transportation System Concept of Operations is revised, the TSRD will be updated.

The Transportation System Operations Implementation Plan (TSOIP) examines transportation processes and system-wide requirements to identify program interdependencies, decisions that need to be made, the management level at which the decisions should be made, and the system analyses (including evaluations of alternatives) needed to inform decisions and develop requirements. The TSOIP is based on a detailed Transportation System operations process flow and supports development of budgets and resource-loaded schedules. The TSOIP will be updated and program direction will be revised to reflect Transportation System development.

Project level requirements documents are derived from the TSRD and provide further detailed guidance for project level specifications. If no further requirements definition is required at the project level then only a specification will be created. For procurement projects, the specifications are used to develop Requests for Proposals. For projects with a design aspect, project level design reports are written in response to specifications. Design Reports define the selected solutions that meet the Transportation System requirements. Initially, the design reports are conceptual. As additional data become available and analyses are performed, design reports become more detailed and support the preparation of Preliminary Design Reports. Final Design Reports document the intended as-built configuration of the project. Throughout system development the combination of requirements, process flows, and design are tightly coupled and collectively document the basis of requirements and the accompanying design that implements them.

The Transportation Operations Plan (TOP) provides well-defined operations, safety, security, and emergency response guidelines for the Transportation System. The TOP is based on the functional descriptions in the Transportation System Concept of Operations, the requirements in the TSRD, and the system-wide processes identified in the TSOIP. The TOP provides the framework from which detailed operational procedures will be developed. Standard procedures based on the TOP will cover several topical areas, including: campaign planning; shipment tracking; training; emergency response; safety; and security.

Site Campaign Plans are developed based on guidance in the TOP. A Site Campaign Plan contains step-by-step, real-time instructions for completing a shipment from an origin site. A Site Campaign Plan is uniquely developed for each origin site. Site Campaign Plans identify each rail consist or truck convoy, associated casks, and routes for each site. They are then accompanied by site specific shipment "work instructions." All Site Campaign Plans are consistent with DOE Manual 460.2-1, Radioactive Material Transportation Practices Manual. The Annual Shipment Plan is a summary of the anticipated shipping activities for a given year.

The documents described in this section define the technical baseline for project execution of the Transportation System. As the need arises, additional documents will be prepared. (References to these Transportation System documents appear in Appendix B.) 


\section{Section 6}

\section{Parties Interested in the Transportation System}

As Transportation System operations mature, OCRWM will continue to work cooperatively with external organizations, including: Federal agencies; States; Federally-recognized Tribes; local governments; utilities; industry; and other interested parties.

\section{Corridor States/Tribes/Local Governments}

As first responders in emergencies, State, local, and Tribal authorities have a significant stake in safety, security, and emergency response. OCRWM will work with States and Tribes to ensure that information is relayed in a timely manner regarding shipments of HLW and SNF to YM. States and Tribes also have a primary responsibility for protecting public health, safety, and the environment.

\section{Utilities and DOE Sites}

Commercial utilities and DOE sites will coordinate with OCRWM to schedule and plan SNF and HLW shipments. Actions taken by the origin site personnel are the first step in the safe and secure transport of SNF and HLW to the Repository. In order to ensure proper handling and preparation of casks at the origin site, OCRWM will develop training on cask handling for origin site personnel. OCRWM approved training will be provided by training specialists at the origin site. In addition, the origin site operator will train site personnel in proper site procedures for SNF and HLW handling and for DOT compliant packaging, marking, labeling, and shipping paper preparation.

\section{Transportation Industry}

The transportation industry is comprised of commercial carriers, transporter manufacturers, and service providers, as well as cask vendors. Under contract with DOE, vendors design and fabricate the transportation casks used to move SNF and HLW from origin sites to the Repository. Through transporter manufacturers, OCRWM procures railcars, locomotives, and truck trailers used to transport waste casks by commercial carriers along designated routes. OCRWM contracts with service providers to conduct the full-range of operating system services, including management and operation of Transportation System fixed facilities, such as the FMF, the Transportation Operations Center, the EOL Rail Yard, and the Caliente Interchange Rail Yard. 


\section{Section 7}

\section{Transportation System Customers, Project Directors, and Service Providers}

The Transportation System will be designed to meet customer needs effectively. Under Federal direction, operations services providers will perform tasks necessary to accommodate DOE and commercial customers. While customers, project directors, and operators share a common mission, their roles are distinguished by the Transportation System operational activities for which they bear primary responsibility.

\section{Customers}

Principal customer organizations relying on, and contributing to, safe, secure, and effective operation of the Transportation System are: commercial entities holding contracts with DOE for disposal of SNF and HLW; DOE sites with SNF and HLW; and the Repository. The Naval Nuclear Propulsion Program (NNPP) will manage Navy rail shipments to the Repository and coordinate with OCRWM for transportation access via the NRL and the EOL Rail Yard.

\section{Federal Project Directors and Supervisors}

Consistent with DOE Manual 413.3-1, Federal project directors have primary responsibility and authority for planning and executing projects approved by the Energy Systems Acquisition Advisory Board, as well as for procuring necessary equipment, overseeing construction and renovation, and negotiating with operations service providers and commercial carriers to start-up and operate the Transportation System. Federal project directors conduct oversight over all operations service providers and their activities and provide the direct interface between Transportation System customers and stakeholders.

\section{Transportation Security Force}

The OCRWM Transportation Security Force (TSF) secures all SNF and HLW shipments. The TSF will undergo extensive specialized training conducted by DOE security training experts. It is expected that the TSF will be comprised of Federal employees, who follow Federal regulations and protocols.

\section{Transportation Operations Service Providers}

OCRWM will obtain and maintain in working order a large supply of transportation equipment from rolling stock, transportation casks, and ancillary equipment (such as cranes and skids) to communications, safety, and security devices. OCRWM intends to procure, by construction contract, lease, or memorandum of agreement, operating facilities to manage logistics nationally and regionally; maintain transportation equipment; and arrange direct-rail transport to the Repository. Federal procurement officials will issue requests-for-proposal to qualified vendors, suppliers, and construction contractors for Transportation System capital assets.

OCRWM will also use transportation operations service providers to manage and operate the Transportation System. A broad-based single contractor, consortium, or affiliation of contractors, 
with the requisite nuclear and transportation experience, may manage and operate some or all Transportation System operations, including the NRL and other OCRWM facilities. Such contractual arrangements will include: logistics and execution planning for SNF and HLW shipments; management, operation, and maintenance of transportation support facilities; inspection, reassembly, and preparation of OCRWM equipment for dispatch; scheduling carrier services; and routine national and local communications. In addition, specialized service providers will maintain transportation assets and are responsible for equipment certifications, approvals, and operational utility.

\section{Commercial Carriers}

Commercial carriers will transport unloaded casks to origin sites, as well as loaded casks from origin sites to the Repository. DOE will contract with rail carriers, who supply power units, qualified engineers, and line crews for rail shipments. Rail carriers will be FRA-regulated short-line or regional railroads that operate over one or more discrete sections of track, or Class 1 (main-line) railroads with national rail networks. At their respective junctions with Union Pacific (UP), other main-line operators will transfer control of shipments to UP rail crews who will transport trains to the Caliente Interchange Rail Yard in Nevada. From Caliente to the Repository and back, OCRWM will retain a qualified rail operator and carrier to operate trains over the NRL.

For truck shipments, OCRWM will use specialized commercial trucking firms that are certified under the DOE Motor Carrier Evaluation Program (MCEP) and will provide DOT-certified drivers qualified for SNF and HLW shipments. Special arrangements will be made for HHT carriers and barge operators. Details on the responsibilities of commercial carriers will be explained in each Site Campaign Plan. 


\section{Section 8}

\section{Description of the Transportation System Major Operational Stages}

The OCRWM Transportation System is a "closed-loop" operational system originating with shipment planning and dispatch from the Fleet Management Facility (FMF). Initially, new empty casks and transporters depart from the FMF for pre-arranged origin sites, where they are loaded, then shipped to the Repository, unloaded, and returned to the FMF for maintenance, reassembly, inventory, inspection, and preparation for a new shipment. Figure 8-1, "Closed Loop" Transportation System, depicts this recurring operational cycle.

\section{Figure 8-1 Closed Loop Transportation System}

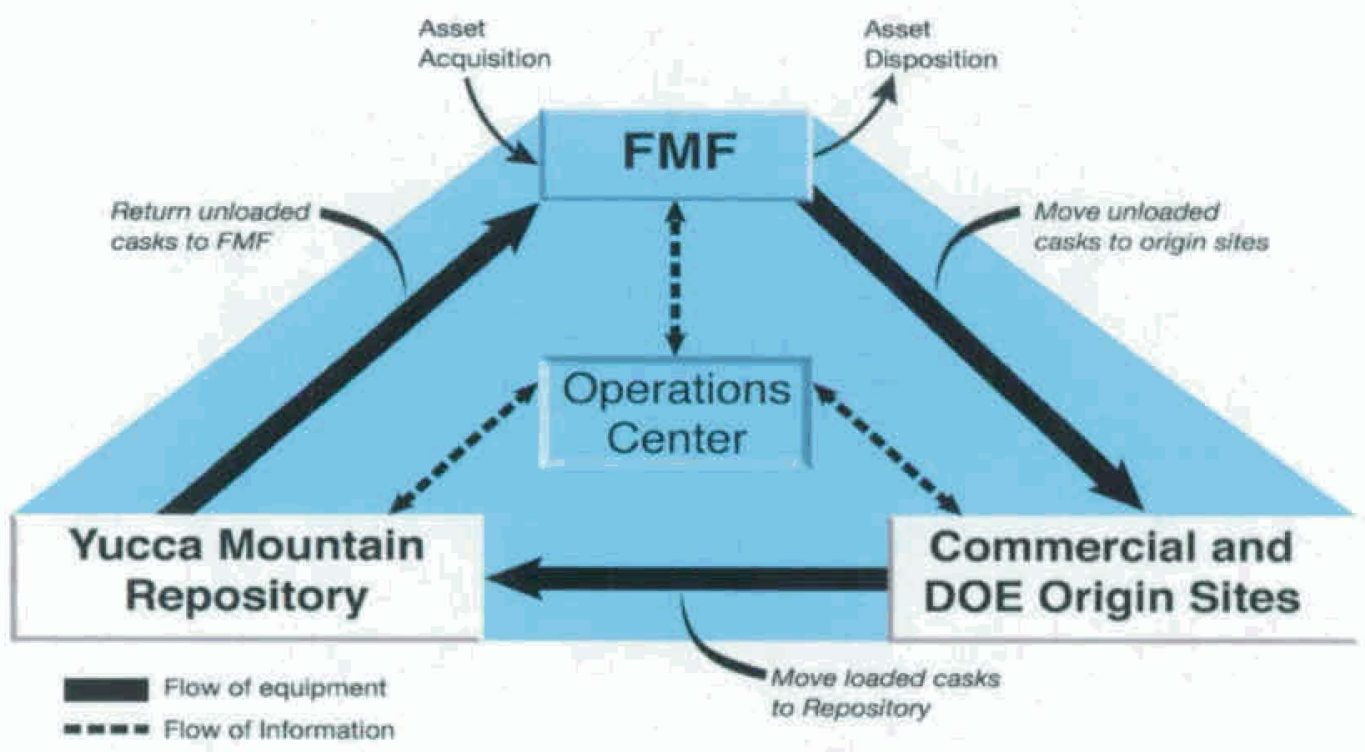

The Transportation System operational cycle is comprised of eight major stages as depicted in Figure 8-1. Defined in a series, each stage consists of discrete functions or activities, operating processes, and interdependent relationships or interfaces among customers, managers, and operators.

(1) Shipment Planning and Management

(2) Assembly and Dispatch from the FMF

(3) Delivery to Origin Site

(4) Cask Handling and Loading at Origin Site

(5) Transporting Loaded Casks to the Repository

(6) Retrieving Unloaded Casks from the Repository

(7) Return of Rolling Stock and Auxiliary Equipment

(8) Reassembly and Preparation for Shipment 


\section{(1) SHIPMENT PLANNING AND MANAGEMENT}

Functions and Activities - Shipment Planning and Management - Shipment Planning and Management is the initial stage of the Transportation System operational cycle. During this stage, capabilities necessary to transport SNF and HLW from origin sites to the Repository are defined. Shipment planning includes the development of shipment schedules and assignment of equipment and personnel necessary for the successful completion of a shipment. Operational shipment planning and management relies heavily on information provided by the commercial utilities and DOE sites via Final Delivery Schedules (FDS) and Repository throughput capacity. Well-defined Transportation System operations, physical security, and emergency response guidelines in the Transportation Operations Plan (TOP) are also required for shipment planning and management.

Data received from SNF and HLW origin sites via the FDSs is used to develop the Annual Shipment Plan and the Site Campaign Plan for each origin site. A shipping campaign correlates the unique logistics requirements at each origin site with transportation system capabilities (e.g., specific casks, equipment, and transportation modes) available for accepting and transporting SNF and HLW in one or more shipments from those origin sites.

Each Site Campaign Plan contains accurate and precise logistical arrangements for transporters, including: assignments of equipment and personnel; specifications for transportation casks and equipment; schedules of arrivals and departures; special requirements; inspections; and time allocations for work activities, as well as specific security and emergency response requirements for a shipping campaign. All Site Campaign Plans are consistent with the DOE Manual 460.2-1, Radioactive Material Transportation Practices Manual.

OCRWM is using advanced optimization-based modeling software to assist in formulating shipment plans that will maximize efficient use of transportation assets and reconcile shipment plans with Repository operations. The Transportation Operations Management (TOM) model is being developed in three phases, which correspond to the system planning, acquisition planning, and operations management phases of the Transportation System. As the Transportation System matures, more complete data and information will be available for model inputs and outputs.

The model supports long-range investment strategies and decision-making about the size of the transportation fleet and characteristics of Transportation System assets including casks, rolling stock, and facilities. The model integrates the full inventory of SNF and HLW and will be used to evaluate the impact of various acquisition profiles on rail, highway, and barge shipment configurations. These advance analyses reduce the time and resources needed to prepare Site Campaign Plans.

As an operational planning tool, the model is designed to assist managers in determining the appropriate allocation of transportation resources and acquisition of assets for acceptance and transport of SNF and HLW to the Repository: As the model matures, it will develop into a TOM system used to validate real-time judgments during operations, based on current sitespecific material and asset availability data. Routine updates to the system are expected to provide a six-month to two-year planning horizon. 
Once shipments begin, the model is structured to evolve into a real-time TOM system for scheduling and tracking shipments throughout the operational life of the system. As a feature of the Transportation Operations Center, the TOM system can produce routine schedules of carrier and cask movements during each of the eight stages in the Transportation System operations cycle.

Operating Process - Detailed shipment planning begins when information from the Final Delivery Schedule (FDS) is made available to the Transportation Operations Center, so that Site Campaign Plans may be developed. To prepare these Site Campaign Plans, the Transportation Operations Center integrates the origin site requirements with Transportation System capabilities, including: availability of equipment from the FMF, throughput capacity at the Repository, and the operational capacity of the NRL. Necessary handling equipment for an origin site is specified in the Site Campaign Plan and provided to the origin site, before new or unloaded transportation casks arrive at the site. Campaign Kits may include: transfer casks; tools; fittings; fasteners; and other components. Training on the use of Campaign Kit equipment is conducted at the origin site in compliance with its safety basis.

OCRWM selects transport modes taking into consideration the availability of services, equipment, and infrastructure at the origin site. OCRWM concurs with carriers on routes and will be guided by the experience and requirements of: Federal agencies, such as Department of Homeland Security (DHS), NRC, FRA, the Federal Motor Carrier Safety Administration (FMCSA), and the United States Coast Guard (USCG), as well as State and Tribal representatives. Rail shipment routes follow commercial rail lines to the DOE-owned NRL. All shipments are tracked by the Transportation Operations Center.

Prior to dispatch of loaded casks from origin sites, authorized State and Tribal representatives are notified of final route determinations and scheduling, in compliance with NWPA Section 180(b), NRC regulation, and DOE Order 460.2A.

Interfaces - During shipment planning, Transportation System interfaces are with: OCRWM Waste Acceptance (WA) to review and concur on FDSs, and to schedule actual pickup and delivery dates; and the Repository to ensure both timely processing of shipment arrivals and return of rolling stock and casks to the FMF.

Nationally, the Transportation Operations Center communicates with Federal agencies, such as the National Weather Service (NWS), the Federal Bureau of Investigation (FBI), the DHS, FRA and others. The Transportation Operations Center coordinates with commercial carriers, origin sites, and affected State and Tribal officials and is responsible for managing Transportation System internal interfaces, e.g., among the FMF, NRL, and EOL Rail Yard.

\section{(2) ASSEMBLY AND DISPATCH FROM THE FMF}

Functions and Activities - Preparations for shipping SNF and HLW originate with assembly of the shipping consist, and terminate with dispatch of transporters. Both series of events take place at the FMF, the Transportation System equipment-management facility leased or owned by DOE and operated by a private contractor. 
Operating Process - Following the development of a Site Campaign Plan, the Transportation Operations Center identifies and directs the FMF to release specific casks and transport equipment configured for the designated origin sites. The TSF is assigned by the Transportation Operations Center to a security escort vehicle that accompanies each shipment.

Under the current concept, for a rail shipment, a train is configured at the FMF with unloaded casks, buffer, cask, and security escort rail cars, and the locomotive, and then the train is dispatched from the FMF. At minimum, the train includes a locomotive, buffer cars, cask rail cars, and TSF security escort cars. Typically, the train consist is expected to have three cask rail cars with casks affixed. In some circumstances, the train may have multiple locomotives.

For a truck shipment, drivers are deployed to move an unloaded cask by road from the FMF to the origin site, stopping only for necessities and fuel. Truck shipment cask trailers and commercial carrier tractors are matched to meet highway weight limits and to accommodate the origin site infrastructure for cask loading. If multiple truck casks service an origin site, several trucks may be dispatched in a convoy and moved to the origin site in the same fashion as a single truck. The shipment security escort vehicle will be dispatched with the truck cask trailers.

Interfaces - Principal interfaces during assembly and dispatch are among: the Transportation Operations Center, which issues detailed instructions to the FMF, NRL, commercial carriers, and TSF personnel; the FMF, which ensures the ready availability and configuration of origin site-specific casks, ancillary equipment, and transport vehicles; and the origin sites.

\section{(3) DELIVERY TO ORIGIN SITE}

Functions and Activities - Service providers and commercial carriers handle, assemble, transfer, and transport new empty casks or used unloaded casks from the FMF to the origin site. Delivering casks from the FMF to the origin site involves similar activities, whether an origin site is served directly by rail, road, or whether an intermediate transfer of the cask at an IMT site is necessary.

Operating Process - The Transportation Operations Center coordinates with commercial carriers to complete each shipment. For example, Class 1 railroads and over-the road trucking firms provide cross-country hauling of unloaded casks. Short-line railroads move casks and equipment to some origin sites from Class 1 railroads. Physical constraints at some origin sites require rail casks to be transferred at a prearranged public or private IMT to HHT or barge for delivery to the origin site.

In barge cases, the HHT delivers the cask to a dock, where it is transferred onto a barge, transported to an approved receiving location, and then moved by HHT to the origin site. Specialized carrier and rigging contractors operate the HHT, barge, and cranes.

Interfaces - Significant interfaces during transport involve: 'commercial transportation carriers; transfer facility or marshaling yard operations personnel; specialized carriers and rigging operators; origin site personnel; and the Transportation Operations Center. Barge transport interfaces may include USCG and port authorities. The Transportation Operations

Page 25 of 56 
Center communicates arrangements with riggers and carriers for hauling and with railroads to arrange IMT sites for storing cask rail cars. At all times, the Transportation Operations Center maintains communication links with Federal authorities to monitor nationwide conditions that may affect shipment progress and to deploy Federal resources when necessary.

\section{(4) CASK HANDLING AND LOADING AT ORIGIN SITE}

Functions and Activities - Upon arrival at the origin site transfer point, the commercial carrier or HHT operator transfers possession of unloaded casks to origin site operations personnel for handling, loading, sealing, testing, and secure placement on transporters. After loading the casks, the origin site arranges for movement of the casks and railcars into position for OCRWM acceptance.

Operating Process - During cask loading, train locomotives, buffer cars, and the security escort car will remain at the origin site or a local marshaling yard under TSF surveillance. Cask loading operations at the origin site comply with all applicable laws and regulations as required by 10 CFR 961.11 .

The origin site ensures that on-site cask loading of the TAD and other canisters or bare fuel into casks adheres strictly to approved operating procedures, including manuals on cask operations, fuel assembly accountability, safety instructions, and Federal regulations. Origin site cask handling personnel are trained in proper cask operations and the use of tools, fittings, fasteners, and other components in Campaign Kits. Training will include dry-runs of equipment and processes.

The origin site prepares casks for shipment, including radiation and contamination surveys, completing documentation, and labeling of the casks. After WA obtains written certification that every cask is loaded properly, the Transportation Operations Center directs the commercial carrier to begin shipment in accordance with DOE, NRC, and DOT regulations. Waste loading and acceptance activities must be coordinated well in advance to allow the Transportation Operations Center to prepare the pre-shipment notifications.

Interfaces - Principle interfaces during site cask operations are among: the origin site; WA; and the Transportation Operations Center. Origin site operations follow schedules in the Site Campaign Plan for SNF or HLW removal, cask loading, and shipment preparation. The origin site certifies that SNF or HLW meets all applicable laws and regulations for Repository acceptance, and then loaded casks are transferred to contract carriers for shipment.

Shipping papers and documents are then prepared by the Transportation Operations Center and electronically transmitted to carriers to generate appropriate way bills. The Transportation Operations Center coordinates pre-shipment inspections by Federal or State agencies, including FRA-inspection of cask and consist railcars and truck inspections conforming to Commercial Vehicle Safety Alliance (CVSA) enhanced inspection standards. 


\section{(5) TRANSPORTING LOADED CASKS TO THE REPOSITORY}

Functions and Activities - Following WA certification of loaded casks, Federal FRA or State CVSA inspection of the cask transporters, and transfer to the commercial carrier or HHT operator, OCRWM initiates "gate-to-gate" campaign operations - from the origin site to the Repository.

Operating Process - Each shipment is subject to a distinct set of Federal and State safety inspection protocols. For example, tractor trailer and truck inspections comply with CVSA Level VI, while rail shipment inspections follow 49 CFR 174.92 and the FRA High-Level Nuclear Waste Safety Compliance Oversight Policy. Barge transport is regulated by the USCG under 33 CFR 1-199. Following inspection and cask acceptance for transport, the Transportation Operations Center instructs commercial carriers to transport loaded cask shipments from the origin site to Caliente. Subsequent en route inspections, if necessary, are coordinated to coincide with other mandatory shipment stops.

Some shipments are conducted solely by rail, where origin sites can load casks shipped on cask rail cars. If only one cask rail car can be accommodated at a time, the Transportation Operations Center arranges to use a nearby rail yard, where the train consist can be assembled for dispatch onto interlining railroads, connect to UP, then to the NRL for transport to the Repository.

In some cases, the cask is returned to the IMT site and reattached to the cask rail car. Loaded rail cars are then assembled into an outbound train consist.

With the exception of the TSF, rail carriers assign train operating crews and maintain communications with their dispatch centers. The Transportation Operations Center communicates with railroad dispatch centers which in turn issue crew instructions. Dedicated train service allows railroads to bypass classification yards to expedite shipments. While prescheduled refueling, crew change, and safety inspection stops are necessary, rail transport interruptions will be minimized by using dedicated train service.

Truck casks are shipped from a single origin site one at a time, or they may be shipped in multiples as part of a convoy. TSF personnel accompany the truck shipment from the moment it departs the origin site until it arrives at the Repository. Truck cask shipments follow DOTcompliant routes designated in the Site Campaign Plan, moving directly from the origin site to the Repository. In some cases, truck carriers may transfer casks onto rail cars at IMT sites or marshalling yards. Truck refueling, required tractor and trailer safety inspections, driver change-outs, and personal needs stops along the highway will be pre-approved by the Transportation Operations Center and kept to a minimum.

Prior to each shipment, the Transportation Operations Center makes necessary pre-shipment notifications and conducts briefings on the Site Campaign Plan with affected carriers and TSF personnel.

Interfaces - Primary interfaces while transporting SNF and HLW are: the origin sites; the commercial carriers; the Transportation Operations Center, and the NRL. Discrete communications are shared solely with those having a need-to-know. These may 
include: carrier dispatchers and crews; inspection officials; Federal agencies; and State and Tribal jurisdictions affected by shipments. Depending on the mode of transportation, additional interfaces may be needed with: marshaling yards; IMT sites; rigging, crane, HHT, and barge operators; and port authorities. At the termination of this stage, safeguards and security integration mandates that seamless transfer occurs from the TSF to the Repository security force.

\section{(6) RETRIEVING UNLOADED CASKS FROM THE REPOSITORY}

Functions and Activities - Rail shipments arrive via NRL and are processed through the Transportation System EOL Rail Yard outside of the GROA. Truck shipments are made across public highways to DOE controlled roads and enter the GROA directly at the security portal. At this stage, the focus of the Transportation System shifts to retrieval, maintenance, and reassembly of shipping casks and equipment as safely and expeditiously as possible for return to productive service.

Operating Process - When a rail shipment arrives at the EOL Rail Yard, the train consist is decoupled. The NRL locomotive, buffer, and security escort cars proceed to the FMF, while train cask rail cars are taken via a GROA switch engine to the Repository. At the Repository, the loaded cask rail cars undergo incoming security and radiological inspections. Cask rail cars are returned via a GROA switch engine to the EOL Rail Yard, and sent to the FMF as promptly as possible. Trucks arriving with loaded casks proceed into the GROA, where they are inspected, the cask/trailer combination is parked, and the tractor is released to the carrier.

At the Repository, casks are unloaded, decontaminated, and certified for public transportation, then placed onto rail cars or truck trailers and sent to the FMF to be prepared for outbound shipment. To preserve OCRWM operational effectiveness throughout the unloading stage, the Repository returns casks and equipment expeditiously to the Transportation System. Each return is identified as ready for in-commerce shipment or as needing maintenance and repair.

Interfaces - Interfaces include: the NRL at the EOL Rail Yard; the FMF; the Transportation Operations Center; and the GROA. Key program interfaces occur when the Repository returns unloaded casks to the FMF.

\section{(7) RETURN OF ROLLING STOCK AND AUXILIARY EQUIPMENT}

Functions and Activities - After arrival at the EOL Rail Yard, a train consist is uncoupled, then locomotives, buffer cars, security escort cars, and any accompanying auxiliary equipment are returned to the FMF for inspection, maintenance, and necessary repairs in preparation for subsequent shipments.

Operating Process - The Transportation Operations Center schedules and manages communications on train consist arrivals at the EOL Rail Yard. The EOL Rail Yard Master directs uncoupling, inspections, and transfers of escort and buffer rail cars to the FMF for fleet maintenance. Highway shipment security escort vehicles are also directed to the FMF. TSF debriefings are conducted at the FMF. All EOL Rail Yard and FMF activities comply with DOE Orders. 
After removal of loaded casks, decontaminated cask rail cars and trailers are checked and returned from the GROA, and they are sent promptly to the FMF for routine repairs and maintenance. Timely movement and exchange of inactive rolling stock, trailers, and equipment from the Repository to the FMF are critical. EOL Rail Yard and dedicated rail spur access points facilitate the expeditious transfer of rail cars to the FMF.

Interfaces - The Transportation Operations Center manages information interchanges and coordinates logistics among NRL, EOL Rail Yard, and FMF operators, and between Repository waste acceptance and transportation operations personnel. The Transportation Operations Center issues transport time allocations and work orders, and monitors schedules to deliver available rail cars, buffer cars, security vehicles, and transportation casks in the shortest time possible from the EOL Rail Yard to the FMF for reshipment, and trucks and trailers from the GROA to the FMF.

\section{(8) REASSEMBLY AND PREPARATION FOR SHIPMENT}

Functions and Activities - Reassembly and preparation for shipment consists of maintenance, inspection, reconstitution, and re-supply of transportation vehicles and equipment prior to and in preparation for deployment or reshipment.

Operating Process - Two consistently reliable and effective maintenance programs are implemented at the FMF - the first focuses on transportation fleet equipment maintenance operations at non-radiological premises; the second focuses on cask reconfiguration, routine maintenance, and repair, some of which is to be performed at a facility that accommodates lowlevel radiological decontamination.

Repair, reassembly, and final inspection of transporters, equipment, and supplies conducted at the FMF complete the final stage in the shipment cycle. These functions include: maintenance operations; minor repair of rail cars, truck trailers, and government-owned and ancillary equipment; replenishment of parts; equipment storage; status tracking of all transport equipment; and records management.

The Transportation Operations Center monitors FMF reassembly and preparation processes in coordination with the NRL and the EOL Rail Yard and issues schedules and directives for integrating FMF operations with the Repository, WA, and origin sites. After the Transportation Operations Center initiates a new or continuing site campaign, and the FMF verifies operational capability, the Transportation Operations Center issues dispatch orders to assemble a new train consist and assigns TSF for its delivery to an origin site. This is the beginning of a new waste shipment cycle.

At the FMF, OCRWM-supplied equipment for cask loading and shipping at origin sites is identified, inspected, calibrated, and assembled into a Campaign Kit. A Campaign Kit may include: TAD system transfer cask; cask-specific lifting yokes; hook adapters; gaskets; seals and leak testing; drying vacuums; and monitoring systems unique to casks described in the Site Campaign Plan. A Campaign Kit is sent by commercial motor carrier to an origin site in advance of the initial shipment to ensure that the origin site is properly equipped and has examined fit-up of adapters and other cask handling equipment. When a Campaign is 
complete, or Campaign Kit components require servicing or routine maintenance, Campaign Kit equipment is returned to the FMF for decommissioning, or inspection, maintenance, testing, and reassignment or return to inventory, as appropriate.

Interfaces - Transportation System operations converge as rolling stock and equipment arrive at the FMF. Internal interfaces managed by the Transportation Operations Center include communication, coordination, and integration with: commercial rail and truck carriers, on the timing and condition of shipments; the NRL, on train consist arrivals; the EOL Rail Yard, on work-process and equipment transfers; the Repository, on scheduling of available unloaded clean casks; and the FMF where, after final inspection, train consists and truck shipments are reassembled with equipment, and features stipulated in the Site Campaign Plan.

The Transportation System cyclical process flow will be repeated throughout the Repository licensing period to assure effective transportation of SNF and HLW from origin sites and delivery to the Repository. The stages of this recurring process are summarized in Figure 8-2 and Table 8-1 which follow.

\section{Figure 8-2 Transportation System Process Flow}

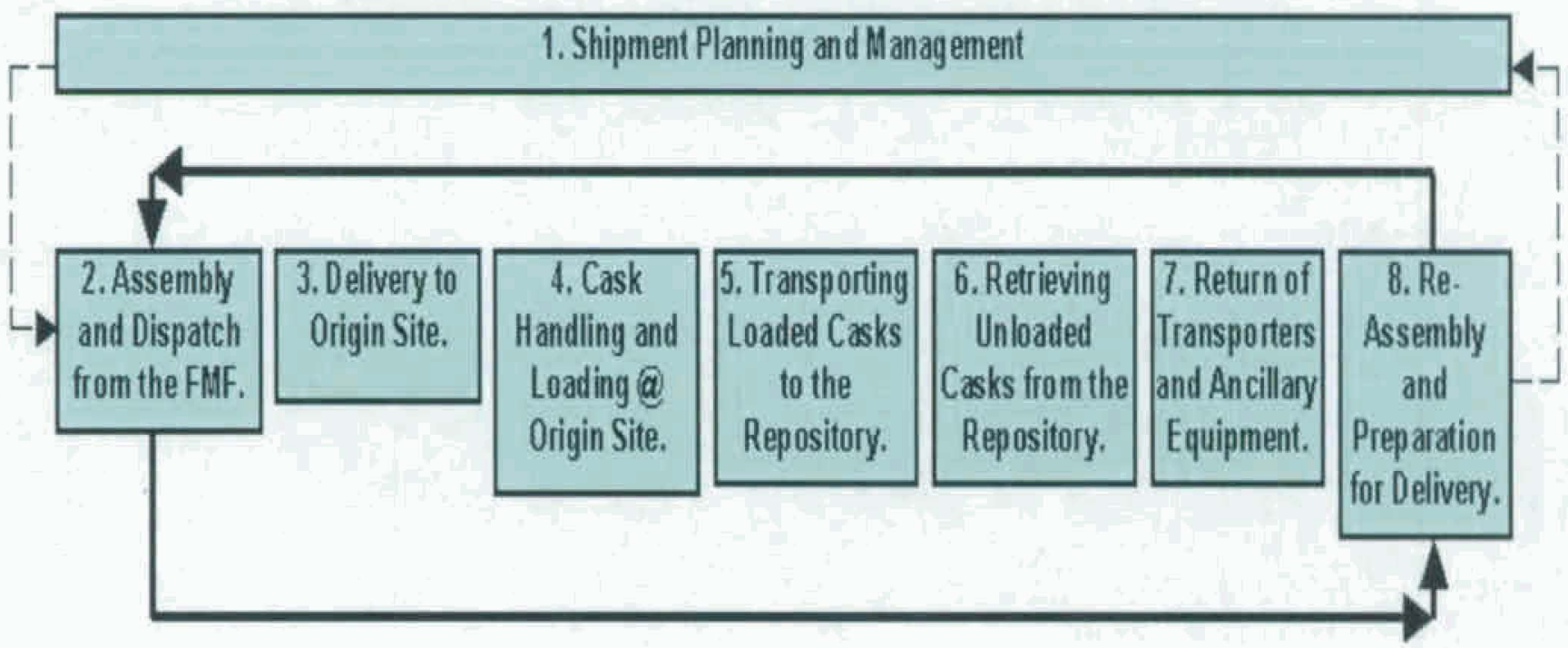




\section{Table 8-1 Transportation System Operational Stages}

Function / Activity

Operating Process

Interfaces

\section{(1) Shipment Planning and Management}

All modes: Plan

Campaigns and Individual

Shipments
Transportation Operations Center (TOC) develops Annual Shipment Plan. TOC also develops a Site Campaign Plan specific to an origin site, using real-time inventory data and resource optimization modeling for assigning casks and equipment to each shipment, including selection and briefing of TSF.
WA provides the FDS input to Annual Shipment Plan for TOC development. FMF provides equipment schedules and readiness data to TOC. TOC develops Site Campaign Plan; coordinates with FMF, Repository, carriers, and origin sites to communicate readiness. Coordination with the FRA will insure any necessary inspections are conducted.

\section{(2) Assembly and Dispatch from the FMF}

Rail: Assemble and move outbound consist from FMF to Caliente Interchange Rail Yard

Highwav: Assemble tractors and trailers; move shipment from FMF to public highway
The FMF identifies shipment ready casks and configuration for origin site, identifies other railcars and assembles consist for dispatch.

FMF identifies shipment ready casks and the configuration for origin site and other needed vehicles for assembly and dispatch.

\section{(3) Delivery to Origin Site}

Rail: Deliver outbound consist

Highway: Deliver outbound truck
The NRL delivers consist to UP for delivery to interlining carriers; servicing carrier delivers to origin site designated delivery point.

A commercial motor carrier hauls casks to origin site and delivers to origin site designated delivery point.
TOC request to NRL, UP, and other rail carriers.

\section{- via Inter-Modal Transfer (IMT)Site}

\section{Rail and Highway/ Heavy Haul/Barge: \\ Transfer casks to alternate mode and move to origin site}

The TOC identifies IMT site where train is delivered. Casks are transferred by mobile or fixed crane to HHT. The HHT is used from a barge, as required, to deliver casks to origin site or assigned place for cask loading.
TOC communicates with FMF to confirm dispatch orders and gives instructions to FMF, NRL or commercial truck carrier, and TSF personnel. TOC schedules intransit TSF protection.
TOC makes request to commercial motor carrier. 


\section{(4) Cask Handling and Loading at Origin Site}

All modes: Move casks into origin site and wait for certification of loaded casks
While casks are loaded at an origin site, other rolling stock equipment is temporarily stored at an approved location onsite or offsite. When casks are loaded, the origin site notifies the TOC, based on confirmation by WA, loaded casks are picked up. All casks in transport are accompanied by TSF personnel.
Carrier notifies TOC of arrival at origin site. TOC notifies WA of arrival. The origin site operator transfers casks from carrier to on-site loading or staging location. A certification is issued at the site and transmitted to WA when a loaded cask is ready for transport. The TOC is notified.

\section{(5) Transporting Loaded Casks to the Repository}

All modes: Transport loaded casks to Repository
The carrier accepts loaded casks after WA approval. Transfer of the cask to a commercial vehicle (i.e., cask car, truck trailer, HHT trailer, or barge) is the next step. If using the RR, rail transport is via Class 1 and $2 \mathrm{RR}$ to the Caliente Interchange Rail Yard. Upon transfer to the NRL, appropriate in-coming DOE inspections are made. At EOL Rail Yard, train cask cars are cut and delivered to GROA portal via GROA locomotive. All casks in transport are accompanied by the TSF. Truck casks are also transported from public highway to Repository access road and security portal at this time.
TOC and carrier verify shipping manifests, inspection decals, etc. TOC personnel coordinate transfers from origin site to commercial carrier; verifies shipping configuration and placards; approves dispatch. TOC and carriers track shipments to the NRL.

\section{- via Inter-Modal Transfer (IMT) Site}

\section{Heany Haul/Barge and Rail and/or Highway: Transfer} casks from alternate mode to rail and move to Repository
HHT carriers or barge operators deliver casks on HHT or barge to IMT site and transfer to rail cars using mobile or fixed cranes. Rail transports casks to EOL Rail Yard outside Repository.
TOC dispatches a crane, LWT, HHT, and/or barge operator(s)

\section{- or via Marshaling Yard}

Rail: Assemble crosscountry rail consist from smaller consists
Carriers move smaller rail consists from origin site(s) or IMT site(s) to marshaling yard and assemble cross-country rail consist, deliver cross-country train to Caliente.
TOC instructs short line and main line RR dispatches. TOC schedules in-transit TSF protection. 
Function / Activity

Operating Process

Interfaces

\section{(6) Retrieving Unloaded Casks from the Repository}

\section{Rail or Highway:}

Repository accepts casks and unloads
The Rail consist is cut at the EOL Rail

Yard. Cask cars retained at EOL Rail

Yard and others sent to the FMF;

Repository locomotive pulls cask cars into GROA where radiation survey and security screening of casks is conducted. The Repository removes waste, decontaminates unloaded casks, identifies casks for FMF, and returns emptied casks to EOL Rail Yard. EOL Rail Yard accepts casks/rail cars outside vehicle portal; and sends casks to FMF for routine maintenance and repair. Trucks carry unloaded casks directly from the Repository to the FMF.
TOC coordinates all Caliente, NRL, and EOL Rail Yard communications. TOC notifies the YM Repository of shipment and transfer schedules. Repository accepts casks, notifies TOC on receipt and waste removal status. All rail yard activities are performed under the direction of the respective Rail Master.

\section{(7) Return of Rolling Stock and Auxiliary Equipment}

\section{Rail and Highway:}

Move rolling stock and transport trailers to FMF
Disassemble rail car consist at the EOL Rail Yard. Send locomotive and rolling stock and any unloaded casks and cars to FMF for maintenance. Trucks move directly from the Repository to the FMF.
TOC exchanges equipment status information with NRL, EOL Rail Yard and FMF. TOC monitors Repository activities for cask returns to EOL Rail Yard and FMF.

\section{(8) Reassembly and Preparation for Shipment}

\section{Rail and Highway:}

Maintenance, repair, staging, and redeployment
FMF receives and stores transporters that have passed inspection and for which routine maintenance is up to date. FMF inspects rail cars and trailers for defects, performs routine maintenance; and then segregates cars with major defects for repair. At the FMF, NRL locomotives are refueled, equipment is stored, contaminated components are segregated and protected. The FMF provides instruments, tools, and facilities for inspection and repairs, and reassembly of consist with empty casks.
FMF notifies TOC of equipment arrivals and status for deployment. TOC provides instructions for FMF on new Campaign Plan configuration. FMF assembles consist or convoy for shipment. TOC dispatches new shipment. 


\section{Section 9}

\section{OCRWM Transportation System Support Environment}

The OCRWM Transportation System support environment is comprised of the facilities, equipment, and services needed to sustain the transportation operations process cycle for disposal of SNF and HLW. The Transportation System facility infrastructure consists of five primary facilities: the Transportation Operations Center; the FMF; the NRL; the Caliente Interchange Rail Yard; and the EOL Rail Yard. As site selections for these facilities are made, the Transportation System Concept of Operations will be updated.

The breadth of the OCRWM disposal program involves annual SNF and HLW shipments from multiple origin sites. To prepare, OCRWM is managing several acquisitions of Transportation System components simultaneously. OCRWM is adhering to the disciplined set of requirements in the TSRD and has individual project plans to guide acquisitions of facilities, equipment, and services in accordance with DOE 413.3.

The OCRWM Transportation System intends to use commercial carriers and transportation operations service providers to operate support facilities necessary to maintain safe and secure operations. Where possible, OCRWM is seeking opportunities to leverage existing resources and expertise to build and operate the Transportation System and will establish and maintain Federal partnerships to gain access to facilities, equipment, and services to benefit Transportation System performance.

\section{Transportation Operations Center}

The function of the Transportation Operations Center is to manage all aspects of the Transportation System, coordinate communications about shipments, and control interfaces between origin sites and the Repository. The Transportation Operations Center manages routine, contingency and emergency transportation operations involving interfaces with multiple entities. The Transportation Operations Center plans and schedules shipments, dispatches transportation assets to origin sites, maintains centralized tracking and control of shipments, secures shipments, communicates origin site and Transportation System activities across the United States, and manages Transportation System assets, which include human, mobile, and fixed assets.

To support planning, the Transportation Operations Center tracks the operational status of all system assets. Both the FMF and Repository will continually update the Transportation Operations Center with the location and operational condition of canisters, casks, rolling stock, and ancillary equipment. In addition, the Transportation Operations Center schedules, assigns, and dispatches TSF personnel to support shipments, training, and, when necessary, emergency response.

At all times, the Transportation Operations Center monitors weather conditions, interstate traffic, and national intelligence, and maintains centralized control of shipments, including en route tracking and status reports on origin site and transportation activities across the United States. 
The Transportation Operations Center activates the DOE emergency response system to provide radiological assistance and to institute Continuity of Operations and Continuity of Government (COOP/COG) when necessary. Table 9-1 describes the Operation Center capabilities at each step of the process.

Table 9-1 TRANSPORTATION OPERATIONS CENTER

\begin{tabular}{|l|l|}
\hline $\begin{array}{c}\text { Transportation } \\
\text { Operations Center } \\
\text { Function }\end{array}$ & \multicolumn{1}{|c|}{ Capabilities } \\
\hline Shipment Planning & $\begin{array}{l}\text { Computer facilities and data bases for deliberate national shipment } \\
\text { planning, scheduling, dispatching, logistics control and operational } \\
\text { improvements nationally. Primary interface for origin sites with } \\
\text { OCRWM. }\end{array}$ \\
\hline Shipment Tracking & $\begin{array}{l}\text { Nationwide shipment tracking systems with satellite and land-line } \\
\text { communications. Back-up tracking systems at DOE authorized } \\
\text { COOP/COG to prevent shutdown disruption in emergency. }\end{array}$ \\
\hline In-transit Shipments & $\begin{array}{l}\text { National communications systems: satellite; cellular; and land-line } \\
\text { links across the United States. Back-up COOP/COG. }\end{array}$ \\
\hline $\begin{array}{l}\text { Emergency and } \\
\text { Security Management }\end{array}$ & $\begin{array}{l}\text { Emergency and security coordination for all in-transit shipments. } \\
\text { Coordination with Federal, State, and local emergency response and } \\
\text { security agencies. }\end{array}$ \\
\hline Personnel Scheduling & $\begin{array}{l}\text { Scheduling system for all Transportation System operations staff, } \\
\text { including TSF, trainers, and dispatchers. }\end{array}$ \\
\hline
\end{tabular}

\section{Fleet Management Facility}

The Fleet Management Facility (FMF) is the primary equipment storage, maintenance, repair and test, inspection, assembly, staging, and dispatch facility for the OCRWM Transportation System. OCRWM plans for the FMF to be a federally-owned or leased, contractor-managed and operated facility with adjoining rail and truck yards. FMF buildings and structures are located together in a single area or separated depending on functions performed. Incoming used equipment is monitored in a low-level radiological area. Non-contaminated equipment is kept separate from contaminated equipment in accordance with "start-clean/stay-clean" practices. Low-level radiological work performed at the FMF is in a distinct area separate from non-radiological maintenance work. Some FMF buildings and structures may be located near the Repository, outside the GROA, while others may be more distant.

The FMF receives new equipment and maintains in-use inventory of rolling stock, casks, trailers, skids, assembly and auxiliary equipment necessary for a fully operational Transportation System throughout the Repository licensing period. In general, minor repairs and maintenance of rolling stock and transporters are completed at the FMF. Major refurbishment or rebuilding of rolling stock and cask trailers is performed at off-site vendor establishments. The decision whether to repair equipment at the FMF is made on a case-by-case basis. 
The FMF services transporters, casks, and equipment for the OCRWM Transportation System. Though rolling stock used by the Naval Nuclear Propulsion Program (NNPP) is not expected to be routinely maintained at the FMF, minor repairs may be arranged.

The FMF is comprised of general and specialized maintenance buildings and secure, accessible yards for rolling stock and cask trailers to support the Transportation System. There are work stations for crews; areas for tools, and storage for surplus equipment, spare parts, and contaminated and uncontaminated casks and auxiliary equipment. Since the FMF is the principal transportation equipment interface for carriers, operators, and service providers in the State of Nevada and throughout the Nation, equipment and crews dispatched from the FMF are qualified to handle SNF and HLW transportation equipment in compliance with Federal and industry standards. The FMF has the capability to service, inspect, repair, and maintain rolling stock and cask trailers. The equipment for NRL track and structures (i.e., maintenance of way equipment) may be stored, repaired, and maintained at the FMF. Cask maintenance and cask recertification are performed at the FMF in authorized low-level radiological work areas. Cask maintenance and recertification activities are performed according to NRC-approved quality assurance programs.

The Transportation Operations Center directs the FMF in preparing equipment for the execution of Site Campaign Plans and all other operational activities supporting shipment security and emergency response as shown in Table 9-2. Interfaces between the FMF, the Repository, and Waste Acceptance are managed by the Transportation Operations Center.

\section{Table 9-2 FLEET MANAGEMENT FACILITY (FMF) FUNCTIONS}

\begin{tabular}{|l|l|}
\hline \multicolumn{1}{|c|}{ FMF Function } & \multicolumn{1}{c|}{ Capabilities } \\
\hline $\begin{array}{l}\text { Inventory Control and } \\
\text { Dispatch }\end{array}$ & $\begin{array}{l}\text { Transportation Operations Center directs FMF to dispatch } \\
\text { Campaign Kits and rail consists or truck convoys to origin sites and } \\
\text { recovers Campaign Kits from origin sites upon completion of each } \\
\text { Campaign. }\end{array}$ \\
\hline Asset Reporting & $\begin{array}{l}\text { Maintains communications with the Transportation Operations } \\
\text { Center on status of shipping assets, and coordinates asset } \\
\text { management with the Transportation Operations Center to facilitate } \\
\text { campaign and shipment planning. }\end{array}$ \\
\hline $\begin{array}{l}\text { Inventory Repair } \\
\text { Supplies }\end{array}$ & Supplies and reorders repair parts for casks and other equipment. \\
\hline Maintenance Records & $\begin{array}{l}\text { Manages records of maintenance, inspections, and certifications, as } \\
\text { well as asset acquisition and disposition. }\end{array}$ \\
\hline Domicile Rail Car Fleet & $\begin{array}{l}\text { Provides a domicile or home yard for rail car fleet, NRL and } \\
\text { supplemental rail track and spur access, and switching capabilities } \\
\text { for train receipt and assembly. The FMF can accommodate the } \\
\text { entire OCRWM fleet. }\end{array}$ \\
\hline $\begin{array}{l}\text { Service Fleet Rolling } \\
\text { Stock }\end{array}$ & $\begin{array}{l}\text { Locus for FMF contractor or rolling stock vendors to perform } \\
\text { minor repairs on rail cars and truck trailers; however, major repairs } \\
\text { are conducted at vendor locations. }\end{array}$ \\
\hline
\end{tabular}




\begin{tabular}{|l|l|}
\hline \multicolumn{1}{|c|}{ FMF Function } & \multicolumn{1}{|c|}{ Capabilities } \\
\hline Security Fleet Service & $\begin{array}{l}\text { Provides a secure area to restrict access to security escort cars and } \\
\text { vehicles, to store weapons, ammunition, communications, and } \\
\text { tracking equipment. Provides for replenishment of provisions, such } \\
\text { as food, fresh water, and linens, for the TSF, in addition to refueling } \\
\text { of the onboard generator. }\end{array}$ \\
\hline $\begin{array}{l}\text { Locomotive/ Tractor } \\
\text { Service }\end{array}$ & $\begin{array}{l}\text { Provides refueling, repair, maintenance, and cleaning; however, } \\
\text { major rebuilding is conducted at vendor locations (i.e., railroad } \\
\text { facilities). }\end{array}$ \\
\hline Cask Maintenance & Inspection and repairs to meet cask certification requirements. \\
\hline $\begin{array}{l}\text { New Casks and } \\
\text { Equipment }\end{array}$ & $\begin{array}{l}\text { Delivery station for new casks and equipment and certification of } \\
\text { operability. }\end{array}$ \\
\hline Procedure Validation & $\begin{array}{l}\text { Key personnel conduct procedure validation and training for cask } \\
\text { handlers who support or oversee cask operations at origin sites. }\end{array}$ \\
\hline $\begin{array}{l}\text { Cask Equipment } \\
\text { Warehouse }\end{array}$ & $\begin{array}{l}\text { Includes large-sized storage structures with overhead cranes for } \\
\text { heavy transfers. }\end{array}$ \\
\hline $\begin{array}{l}\text { Ancillary Equipment } \\
\text { Warehouse }\end{array}$ & $\begin{array}{l}\text { Provides storage for all ancillary equipment (e.g., yokes, slings, } \\
\text { cask drying systems, etc.) and manages uncontaminated equipment, } \\
\text { segregated from contaminated equipment. }\end{array}$ \\
\hline $\begin{array}{l}\text { Cask Parts Shipping } \\
\text { Area }\end{array}$ & $\begin{array}{l}\text { Contains a decontamination area to clean previously used parts and } \\
\text { components, as well as a packaging area to prepare Campaign Kits. }\end{array}$ \\
\hline $\begin{array}{l}\text { Ancillary Equipment } \\
\text { Facilities }\end{array}$ & $\begin{array}{l}\text { Includes space for calibrating instruments, and tools used in cask } \\
\text { and system structure and component (SSC) maintenance operations. }\end{array}$ \\
\hline $\begin{array}{l}\text { Provides in-briefings on Site Campaign Plan and boarding prior to } \\
\text { dispatch of TSF personnel. Upon completion of a shipment, TSF } \\
\text { personnel accompany return of security escort vehicle(s) to the } \\
\text { FMF as directed by the Transportation Operations Center. }\end{array}$ \\
\hline
\end{tabular}

\section{Nevada Rail Line}

Based on the completion and approval of the final EIS for the Alignment, Construction, and Operational of a Rail Line to a Geologic Repository at Yucca Mountain, OCRWM plans to construct a new rail line through the Caliente, Nevada corridor directly to the Repository at Yucca Mountain. The NRL is the rail artery used for trains transporting SNF and HLW and other materials between commercial railroads (via the UP mainline) and Yucca Mountain. Upon transfer from UP, and before transport onto the NRL, all loaded casks undergo inspections in accordance with DOE Orders. All rail cars are also subject to security sweeps in conformance with DOE Order 470 before passage to the NRL.

The NRL is owned by DOE and operated by a qualified operating contractor. The principal function of the NRL is the transport of trains containing SNF and HLW shipments from the UP mainline to the EOL Rail Yard outside of the Repository gate. The NRL is also.a route for moving construction and operating supplies to Yucca Mountain. Design of the proposed NRL is contingent on completion of a final NRL Environmental Impact Statement and issuance of a Record of Decision, which is expected to contain design specifications for the Caliente 
Interchange Rail Yard at the UP/NRL junction, as well as the approximately 320 -mile long, single-line NRL track with passing siding at every 30 to 50 miles, and the EOL Rail Yard outside the GROA. Table 9-3 outlines all NRL functions.

\section{Table 9-3 NEVADA RAIL LINE FUNCTIONS}

\begin{tabular}{|c|c|}
\hline NRL Function & $\begin{array}{l}\text { Capabilities } \\
\end{array}$ \\
\hline $\begin{array}{l}\text { Transport Dedicated } \\
\text { Trains }\end{array}$ & $\begin{array}{l}\text { Operates trains to Repository. Minimizes holding time at Caliente. } \\
\text { Moves dedicated trains carrying SNF and HLW to EOL Rail Yard } \\
\text { in } 12 \text { hours. }\end{array}$ \\
\hline $\begin{array}{l}\text { Transport to and from } \\
\text { the Repository }\end{array}$ & $\begin{array}{l}\text { Transports materials to the Repository and FMF in accordance with } \\
\text { Federal regulations. Uses trained and qualified crews. }\end{array}$ \\
\hline $\begin{array}{l}\text { Operate NRL } \\
\text { Locomotives }\end{array}$ & $\begin{array}{l}\text { Operates locomotives compliant with FRA and manufacturer } \\
\text { specifications. }\end{array}$ \\
\hline $\begin{array}{l}\text { Pre-Shipment and } \\
\text { Routine Track and } \\
\text { Structure Inspections }\end{array}$ & $\begin{array}{l}\text { Conducts FRA routine track and structure inspections, prior to } \\
\text { loaded cask transport on the NRL. }\end{array}$ \\
\hline $\begin{array}{l}\text { Maintain NRL Track } \\
\text { and Structures to } \\
\text { Appropriate Standards }\end{array}$ & $\begin{array}{l}\text { Designs, constructs, and maintains track and structures to Class-1 } \\
\text { railroad standards for } 50 \text {-year lifetime. Provides Maintenance-of- } \\
\text { Way equipment to keep track gauge, ballast, cross ties, switches, } \\
\text { control circuits and equipment and other structures including } \\
\text { bridges and grade crossings in like-new condition. }\end{array}$ \\
\hline NRL Train Center & $\begin{array}{l}\text { Implements local traffic control and track switches through the NRL } \\
\text { train center to ensure safety. Coordinates activities through the } \\
\text { Transportation Operations Center. Installs electronic signals to } \\
\text { detect train defects or rail discontinuities. }\end{array}$ \\
\hline $\begin{array}{l}\text { Emergency Response to } \\
\text { In-Transit Incidents }\end{array}$ & $\begin{array}{l}\text { Installs supplemental, temporary track to provide capability to } \\
\text { respond to incidents from either end of the NRL. }\end{array}$ \\
\hline
\end{tabular}

\section{Caliente Interchange Rail Yard}

The Caliente Interchange Rail Yard, located on the UP rail line at or near Caliente, Nevada, is comprised of several rail spurs and other service facilities that constitute the transition between DOE and commercial rail lines. The mission of the Caliente Interchange Rail Yard is to transfer rail traffic expeditiously between UP and the DOE rail lines. Necessary administrative offices, refueling, car turn-around, and switching facilities are also situated at the interchange yard, as well as an area for staging NRL maintenance-of-way or rail track repair equipment.

The NRL operates the Caliente Interchange Rail Yard, while the UP provides commercial carrier services. The Caliente Interchange Rail Yard is located close to the Utah border, and is therefore considered suitable for Nevada inspection prior to transfer to the NRL. Additional details about the functions of the Caliente Interchange Rail Yard are found in Table 9-4.

At Caliente, there is sufficient track and switching capacity to allow at least two trains to pass unencumbered and to permit access for inspections. Rail cars destined for the Repository undergo DOE required inspection before leaving the Caliente Interchange Rail Yard for the NRL. Loaded 
cask rail cars are subject to inspections based on DOE Orders. In the unlikely event that any rail car fails screening, it is set out on a separate track for corrective action. Before leaving the Caliente Interchange Rail Yard for the Repository, all rail cars are inspected for operational defects pursuant to FRA requirements. Unless minor repairs can be made at the interchange yard, rail cars exhibiting defects are issued a "bad-order" notice and cut from the train for subsequent repair. Outbound traffic arriving at the Caliente Interchange Rail Yard from the Repository is staged for pickup by the UP and undergoes FRA-required interchange inspection before release. If other trains are approved for NRL use, they would also be subject to inspections at the interchange prior to entry or exit from the UP to the NRL.

Table 9-4 CALIENTE INTERCHANGE RAIL YARD FUNCTIONS

\begin{tabular}{|c|c|}
\hline $\begin{array}{c}\text { Caliente } \\
\text { Interchange Rail } \\
\text { Yard Function } \\
\end{array}$ & Capabilities \\
\hline UP/NRL Interchange & $\begin{array}{l}\text { UP delivers waste shipment dedicated trains to the Caliente } \\
\text { Interchange Rail Yard for transfer to NRL operating crews and } \\
\text { motive power (or DOE locomotives). Dedicated trains use assigned } \\
\text { locomotives. }\end{array}$ \\
\hline $\begin{array}{l}\text { Incoming Security } \\
\text { Screening (DOE O 470) }\end{array}$ & $\begin{array}{l}\text { At Caliente, an inspection pit, corral, or other structure } \\
\text { accommodates rail cars at least } 100 \text {-feet long with necessary closed } \\
\text { circuit TV, lighting, and personnel access points. Distance from } \\
\text { loaded cask rail cars is established to lower potential radiation } \\
\text { exposures. Interior inspection of railcars (i.e., box cars) is } \\
\text { necessary for closed transporters lacking "see-though" } \\
\text { characteristics. Once inspected, cask rail cars remain under TSF } \\
\text { surveillance. Remote technologies will be used to minimize } \\
\text { exposure. }\end{array}$ \\
\hline Inspections & $\begin{array}{l}\text { Inspections will employ automated instrumentation (i.e., fixed- } \\
\text { position monitors) for safety and efficiency. Accommodations will } \\
\text { be made for technician staging under roof cover. Inspections will } \\
\text { be conducted according to DOE Orders. }\end{array}$ \\
\hline Nevada State Inspectors & Nevada inspections occur at Caliente. \\
\hline Yard Master & $\begin{array}{l}\text { Manages the interchange of railcars and shipping paperwork } \\
\text { between NRL and UP. }\end{array}$ \\
\hline Sidings and Switches & $\begin{array}{l}\text { Sidings and switches allow at least two incoming and two outgoing } \\
\text { trains at the yard and for rail consists to be staged. Personnel use } \\
\text { siding and switches in remote extraction of contraband or } \\
\text { radiological cleanup activities and packaging of radiological } \\
\text { materials for delivery to the Repository for processing and disposal. }\end{array}$ \\
\hline Maintenance of Way & $\begin{array}{l}\text { Rail way and associated equipment enable personnel space for car } \\
\text { turnaround. }\end{array}$ \\
\hline Refueling & $\begin{array}{l}\text { Tank storage for refueling NRL locomotives and UP fuel oil } \\
\text { delivery. }\end{array}$ \\
\hline Emergency Response & $\begin{array}{l}\text { Storage for firefighting and emergency response equipment and } \\
\text { personnel staging. }\end{array}$ \\
\hline
\end{tabular}




\section{End of Line Rail Yard}

The End of Line (EOL) Rail Yard serves as the Transportation System termination point for incoming SNF and HLW rail shipments and as the main conduit for transferring rail casks and equipment to and from the GROA. On the other hand, truck shipments move directly to the Repository rather than through the EOL Rail Yard. The EOL Rail Yard is comprised of rail yards, switching stations, and the necessary support structure to accommodate expeditious transfer of rail fleet equipment and casks between the NRL, FMF, and the GROA. The EOL Rail Yard provides the end-stage access for incoming loaded rail cask cars as shown in Table 9-5.

At the EOL Rail Yard, an arriving train consist is uncoupled, and all cars except loaded cask cars, are returned to the FMF. Loaded cask rail cars are moved via GROA switch engine into the GROA for cask and skid removal and processing. Following radiological surveys (at the GROA) documenting the absence of loose or excessive contamination, rail cars (without skids) are sent from the GROA via the EOL Rail Yard to the FMF, where they are prepared for another shipment. EOL Rail Yard activities are directed by the Transportation Operations Center in coordination with the Yard Master for the EOL Rail Yard. Similar to the FMF, NRL, and the Transportation Operations Center, the EOL Rail Yard is an OCRWM-managed area situated outside of the GROA, regulated under DOE Orders.

Table 9-5 END OF LINE RAIL YARD FUNCTIONS

\begin{tabular}{|l|l|}
\hline \multicolumn{1}{|c|}{$\begin{array}{c}\text { EOL Rail Yard } \\
\text { Function }\end{array}$} & \multicolumn{1}{c|}{ Capabilities } \\
\hline NRL Interchange & $\begin{array}{l}\text { NRL delivers train consists to the EOL Rail Yard for decoupling } \\
\text { and transfer of cask rail cars to the Repository. GROA switch } \\
\text { engines take rail cars to the GROA vehicle access portal. }\end{array}$ \\
\hline EOL Rail Yard Master & $\begin{array}{l}\text { Manages local interchanges and shipping paperwork between NRL, } \\
\text { EOL Rail Yard, and GROA, and directs movement of rail cars to } \\
\text { FMF and GROA. }\end{array}$ \\
\hline Sidings and Switches & $\begin{array}{l}\text { Sidings allow incoming and outgoing trains to pass and are } \\
\text { ALARA compliant. Separate tracks for train decoupling and return } \\
\text { of empty rail cars. }\end{array}$ \\
\hline Wye capacity & Rail wye sufficient to allow car turnaround. \\
\hline $\begin{array}{l}\text { Refueling for NRL } \\
\text { Locomotives }\end{array}$ & Tank capacity for locomotives and local RR fuel oil deliveries. \\
\hline $\begin{array}{l}\text { Maintenance of Way } \\
\text { Equipment }\end{array}$ & Maintenance of way equipment staging to minimize NRL outages. \\
\hline Emergency Response & $\begin{array}{l}\text { Storage for fire fighting and emergency response equipment and } \\
\text { personnel staging. }\end{array}$ \\
\hline
\end{tabular}




\section{Equipment}

OCRWM plans to purchase equipment for SNF and HLW shipments. Specific equipment acquisition plans apply to rail cars, locomotives, truck trailers, and casks, as well as to ancillary equipment and communication hardware and software. To transport waste, OCRWM acquires and provides cask, buffer and security escort cars to the transportation operations contractor for use and resupply. To provide redundancy, it may be necessary to use two locomotives for a shipment. To meet power source demand, locomotives for Transportation System train consists may be provided by common carrier, obtained by lease agreement with railroad service providers, or by purchase. Regulatory compliant truck trailers may also be purchased by OCRWM for operations contractors to haul overweight truck (OWT) or legal weight truck (LWT) casks. The function of each type of car and its capabilities are outlined in Table 9-6.

Table 9-6 TRANSPORTATION SYSTEM TRANSPORTER TYPES

\begin{tabular}{|l|l|}
\hline \multicolumn{1}{|c|}{ Function } & \multicolumn{1}{c|}{ RAIL CARS } \\
\hline Cask Cars & $\begin{array}{l}\text { Capabilities } \\
\text { unil cars to accommodate up to 200-ton loads and provide a }\end{array}$ \\
\hline Buffer Rail Cars & $\begin{array}{l}\text { Provide "buffer" between cask rail cars and personnel occupied rail } \\
\text { cars and locomotives. }\end{array}$ \\
\hline Security Escort Cars & $\begin{array}{l}\text { Provide housing for TSF personnel, advanced communications, } \\
\text { tracking and monitoring equipment, weapons, and ammunition. }\end{array}$ \\
\hline \multicolumn{2}{|c|}{ HIGHWAY VEHICLES } \\
\hline Function & \multicolumn{1}{|c|}{ Capabilities } \\
\hline $\begin{array}{l}\text { Legal Weight Trucks } \\
\text { (LWT) }\end{array}$ & $\begin{array}{l}\text { Legal Weight Trucks must not exceed 34,000 pounds per dual axle } \\
\text { or 17,000 pounds per single axle considering full fuel load, two } \\
\text { drivers, loaded cask, and any additional road, tracking, or disabling } \\
\text { equipment. }\end{array}$ \\
\hline Security Escort Vehicles & $\begin{array}{l}\text { Highway security escort vehicles will meet all applicable highway } \\
\text { safety requirements and shall be outfitted to DOE specifications. }\end{array}$ \\
\hline
\end{tabular}

OCRWM plans to acquire NRC certified casks and ancillary equipment needed to service origin sites. Transportation operations service providers will procure cask related spare parts and other equipment for Campaign Kits and may be given authorization to replenish cask and ancillary equipment stocks once the Transportation System is operating. The capabilities of each cask and its associated equipment are shown in Table 9-7. 
Table 9-7 CASKS AND ASSOCIATED EQUIPMENT

\begin{tabular}{|l|l|}
\hline \multicolumn{1}{|c|}{$\begin{array}{c}\text { Equipment } \\
\text { Function }\end{array}$} & \multicolumn{1}{c|}{ Capabilities } \\
\hline Casks & $\begin{array}{l}\text { Casks with NRC certification that are "suitable-for-use" at each } \\
\text { specific site according to contents, weight, dimensions, and } \\
\text { transportation access limits. }\end{array}$ \\
\hline Transfer Casks & $\begin{array}{l}\text { At some origin sites, special light-weight casks may be used that are } \\
\text { designed to allow for transfer of loaded TADs into transportation } \\
\text { casks without immersing the transportation cask into SNF pools. }\end{array}$ \\
\hline Cask Shipping Skids & $\begin{array}{l}\text { Needed at more than 75\% of origin sites to position casks for } \\
\text { loading and shipment. Interoperable with any OCRWM cask rail car } \\
\text { and provide for cask field transfer without removal of personnel } \\
\text { barriers or impact limiters. Design allows IMT of casks and to } \\
\text { facilitate transfer of rail casks to the Repository. }\end{array}$ \\
\hline Ancillary Equipment & $\begin{array}{l}\text { Cask unique lifting yokes, bolting operators, leak-testing equipment, } \\
\text { other components, testing and measuring instruments and fixtures } \\
\text { for each cask system. Packaging for surface contaminated ancillary } \\
\text { equipment. Transfer casks (used with canister-based systems). }\end{array}$ \\
\hline $\begin{array}{l}\text { Initial Spare Parts \& } \\
\text { Consumables }\end{array}$ & $\begin{array}{l}\text { Fasteners, containment seal rings (gaskets) and service fittings, } \\
\text { valves, unique lubricants, etc. }\end{array}$ \\
\hline
\end{tabular}

\section{Communications System}

The Transportation Operations Center maintains real-time communication links as appropriate with Federal agencies, State and Tribal organizations, and commercial rail and truck control centers to monitor shipment progress, track security and safety conditions, and deploy necessary repair, provisions, or emergency assistance to shipments en route. Communications architecture accommodates cyber security, vendor compatibility, reliable tracking and interoperability, as well as secure and open network interfaces. Hardware and software designs and configurations are compatible across OCRWM and compliant with a comprehensive information management system procurement strategy. Capabilities of the transportation information system incorporate: a shipment tracking system; records management system; modeling programs for shipment planning and routing; and communications dispatch notification systems.

Critical capabilities of communications and information management systems are: shipment tracking; routine transmissions; secure links with other Federal government agencies; and emergency inter-connectivity with emergency response centers within DOE and with other government agencies, commercial carriers, and State and Tribal responders. 


\section{Section 10}

\section{Transportation System Operations Scenarios}

\section{Routine Operations Scenarios}

OCRWM anticipates that routine Transportation System operations generally follow one of several identified scenarios for SNF and HLW shipments from an origin site to the Repository. These scenarios are based on routes selected and instructions issued by the Transportation Operations Center to rail and truck carriers and barge operators in Site Campaign Plans. Train routes are determined based on operational requirements, rail capacity, and security. In general, trains maximize the use of Class 1 rail systems and minimize transit times to the Repository. For the most part, trucks will travel by interstate highways, and other approved alternate routes. Essentially, all shipping scenarios follow a similar process flow, beginning and ending at the FMF; however, the step-by-step progression of each varies since there are physical differences in the origin sites (e.g., the cask handling capability and site access).

The following scenarios are transportation operational cases presented in the narrative, with an accompanying Figure. (More detail on the eight operational stages of the Transportation System is contained in Section 8 of this document.) A typical, straightforward operational scenario involves a single mode of transportation, whereas more complex scenarios require use of multiple transportation modes, inter-modal transfers, and marshaling yards. Additional scenarios describe operating processes for four atypical events. 


\section{(1) Direct Rail Shipment}

The Transportation System conceptual framework is based on the 2004 Record of Decision on the Mode of Transportation for nuclear waste disposal. The decision stated that the "Department would rely on a combination of rail, truck and possibly barge to transport to the Repository... with most of the SNF and HLW being transported by rail." About 70 percent of origin sites are accessible directly by rail. Direct rail is the least complex rail transit cycle. It begins when the Transportation Operations Center schedules a shipment and the FMF releases a rail consist with multiple unloaded casks for transport to the origin site. At the origin site, casks are loaded, then shipped via commercial rail to the NRL and on to the EOL Rail Yard for train consist uncoupling and transfer for Repository processing. The shipment is completed when all equipment is returned to the FMF. Figure 10-1 depicts a Direet Rail Shipment.

Figure 10-1

\section{Direct Rail Shipment}

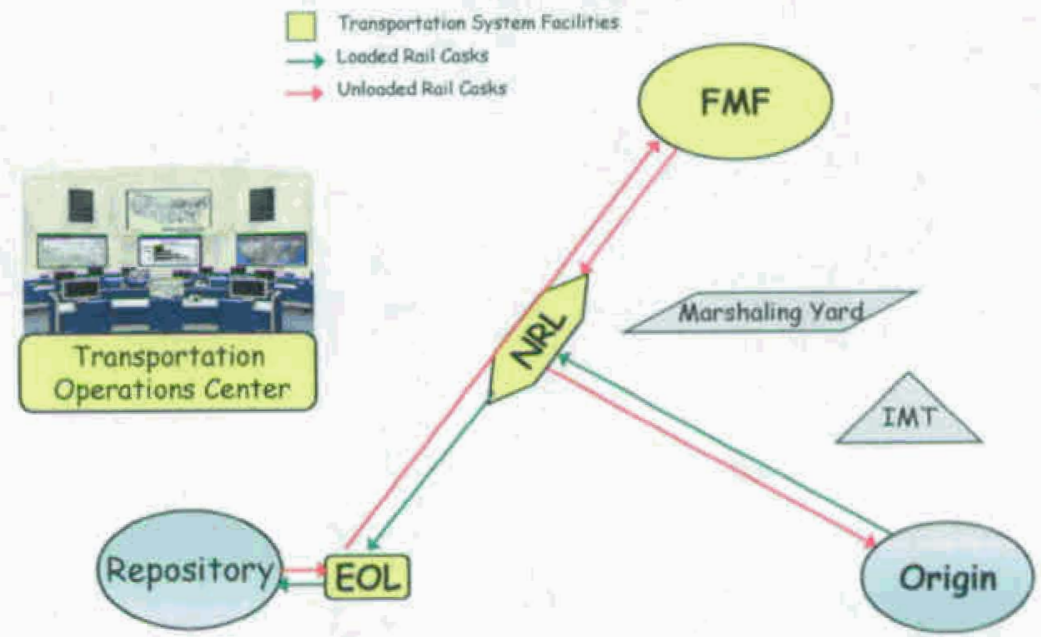

Direct Rail Shipment

Unloaded Casks

- Rail consist assembled at FMF

- Rail consist travels across NRL

- Rail consist transfer to UP at NRL . Caliente Interchange Rail Yard

- Rail consist travels across UP and other interlining railroad carriers to origin site
Loaded Casks

Rail consist departs origin site

Rail consist travels across interlining railroads to UP

UP takes rail consist to NRL. Caliente Interchange Rail Yard

- Train travels across NRL to EOL

- Cask cars cut from train at EOL and moved to Repository

- Auxlliary cars (and available unloaded casks and cars) moved from EOL to FMF 


\section{(2) Rail Shipment via Marshaling Yard}

During a rail shipment, it may be necessary or preferable to use marshaling yards. A marshaling yard allows a rail service carrier to cut a large multi-cask car cross-country train consist into smaller parts, permitting entry of a smaller consist onto a limited access origin site. A local marshaling yard serves as a safe and secure location for holding rail cars while loading is under way at the origin site. Coincidentally, a cross-country consist with loaded casks may also be reassembled and deployed at the marshaling yard. The operational scenario for a rail shipment using a marshaling yard, though similar to direct rail transport, involves more incremental steps. Figure 10-2 shows the operational scenario for a shipment via marshaling yard.

Figure 10-2

\section{Rail Shipment Via Marshaling Yard}

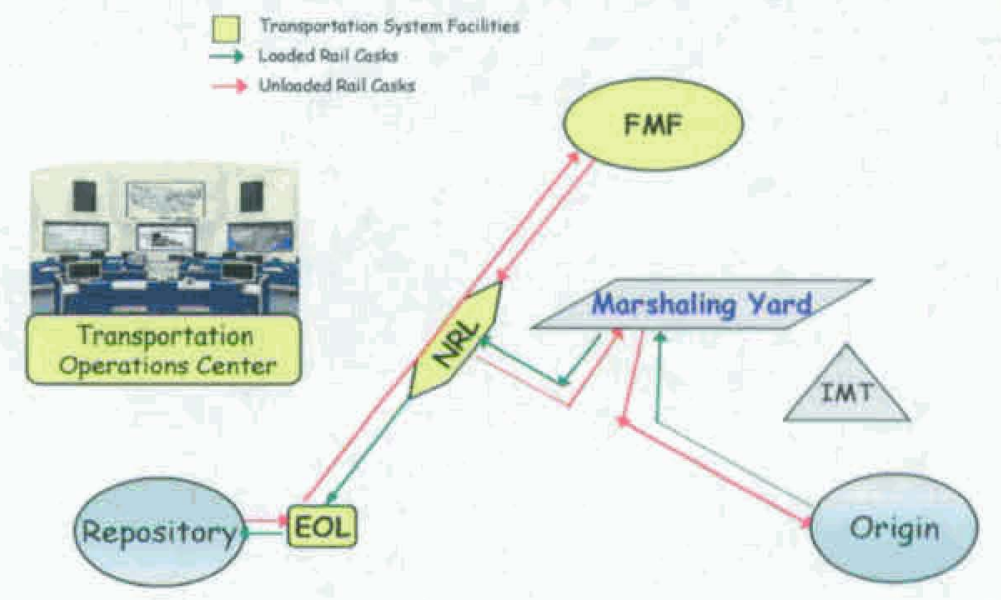

\section{Rail Shipment Via Marshaling Yard}

Unloaded Casks

- Rail consist assembled at FMF

- Rail consist travels across NRL

- Rail consist transfer to UP at NRL Caliente Interchange Rail Yard

- Rail consist travels across UP and other interlining railroads to marshaling yard

- Consist cut into smaller consist (with one rail cask car)

- Small consist moved to origin site

\author{
Loaded Casks
}

Small rail consist departs origin site for marshaling yard

- Smaller rail consists reassembled into large cross-country consist

- Cross-country train travels across interlining railroad carriers to UP

- UP takes train to NRL Caliente Interchange Rail Yard

- Train travels on NRL to EOL

- Cask cars cut from train at EOL and moved into Repository

- Auxiliary cars (and any available unloaded casks and cars) moved from EOL to FMF 


\section{(3) Rail Shipment via Inter-Modal Transfer (IMT) Site}

The use of an IMT site is necessary when an origin site cannot be reached directly by rail. In this case, on-site transfer by HHT or by barge is required. To lift unloaded casks off of a rail car onto a specialized HHT or barge and back to the rail car once loaded, special equipment matched to cask skids is required at IMT sites. It may take several days to complete cask loading and refitting casks onto a train consist bound for Yucca Mountain. Figure 10-3 depicts a rail shipment transfer via IMT site.

\section{Figure 10-3}

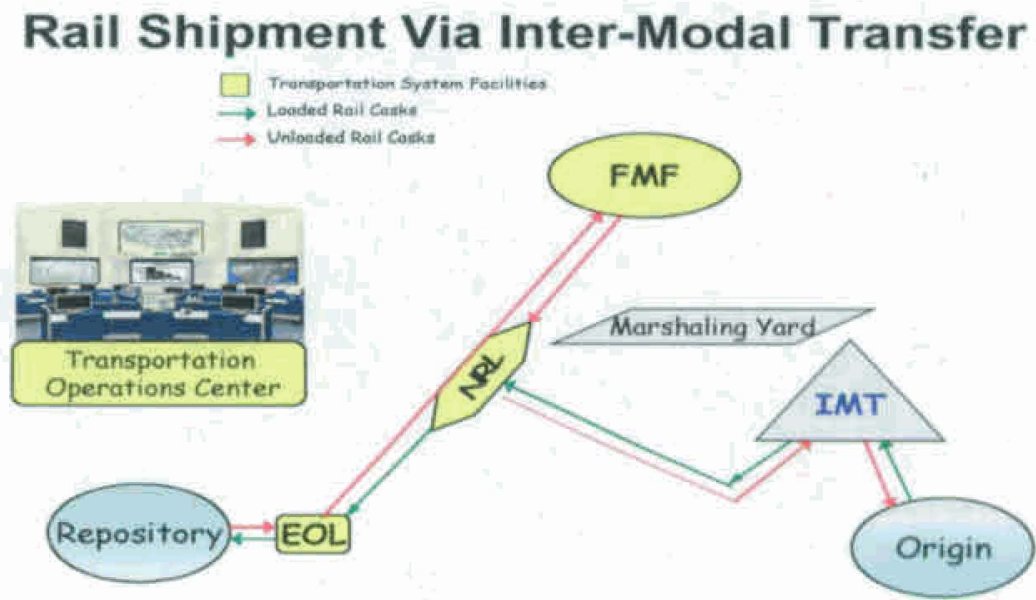

\section{Rail Shipment Via Inter-Modal Transfer}

Unloaded Casks

- Rail consist assembled at FMF

- Rail consist travels across NRL

- Rail consist transfer to UP at NRL Caliente Interchange Rail Yard

- Rail consist travels across UP and other interlining railroad carriers to inter-modal transfer (IMT) site

- Rail casks transferred to heavy haul truck (HHT) or barge and moved to origin site
Loaded Casks

- Rail cask leaves origin site on HHT or barge

- Rail cask transferred from HHT or barge to rail consist at IMT

Rail consist travels across interlining railroad carriers to UP

UP takes train to Caliente Interchange Rail Yard and transfers consist to NRL

- Train travels across NRL to EOL

- Cask cars cut from train at EOL and moved into Repository

- Auxiliary cars (and any available unloaded casks and cars) moved from EOL to FMF 


\section{(4) Rail Shipment via Marshaling Yard and IMT}

For some rail shipments, additional complexities of origin site access and regional rail connections may require use of an IMT site for cask transfer as well as a marshaling yard for cask car layover until a consist can be formed. In some locations, limited space at an IMT site that only accommodates one cask rail car may necessitate reassembly of the train consist at a marshaling yard. Figure 10-4 depicts a rail shipment via marshaling yard and IMT site.

Figure 10-4

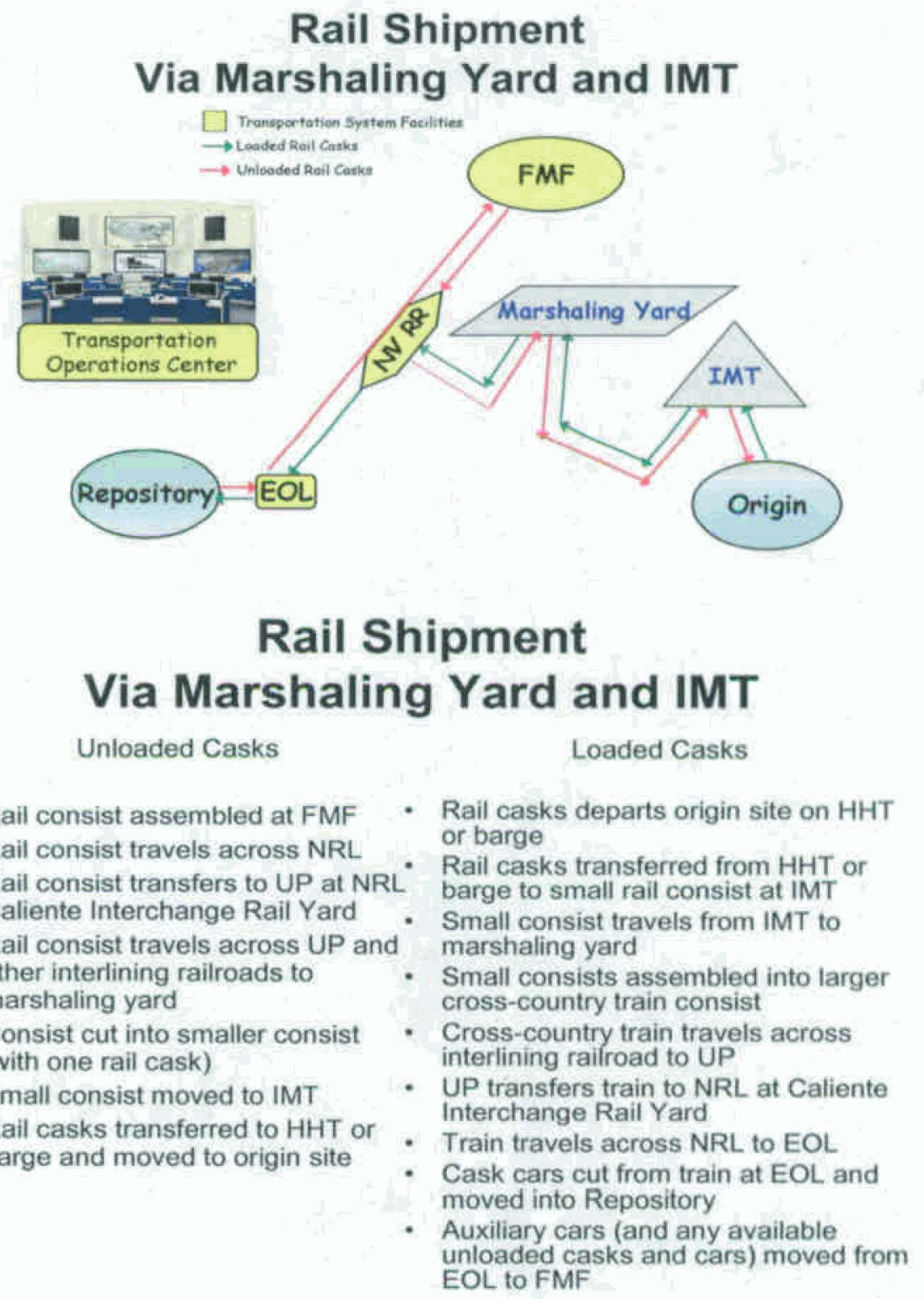




\section{(5) Direct Truck Shipment}

Although truck casks have substantially less capacity, for some origin sites, truck shipments are the only option. These sites lack sufficiently large entry points or cask handling cranes, or other equipment needed to load rail casks. Shipment by truck may also be more effective than rail casks in rare cases, such as near the completion of a campaign, when a partial cask load is all that remains at an origin site. Generally, when casks are transported by truck, shipments are direct; therefore, neither marshaling yards nor IMT sites are needed. However, this does not rule out, on case-by-case basis, the use of "piggybacking" loaded truck casks on rail cars to serve the needs of the Transportation System. Figure 10-5 presents the operational scenario for a direct truck shipment.

Figure 10-5

\section{Direct Truck Shipment}

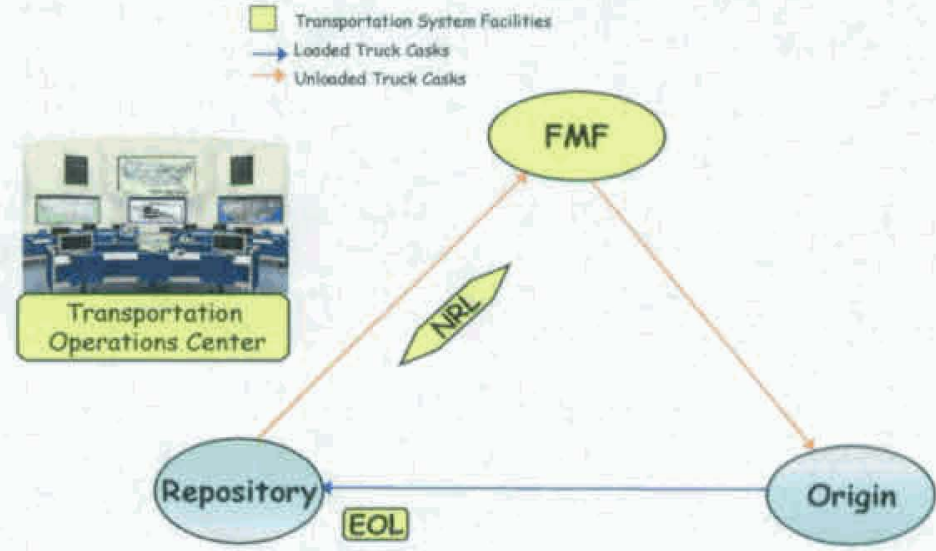

\section{Direct Truck Shipment}

Unloaded Casks

Truck convoy assembled at FMF

- Truck convoy travels to public highway

- Truck convoy travels over public highways to origin facility
Loaded Casks

Truck convoy departs origin site and travels to Federal property boundary near Repository on public highways

- Truck convoy travels Repository controlled access road on Federal property to truck entry at Repository

- Truck casks moved into Repository

- Unloaded casks and trucks move to FMF

Note: Direct truck shipments are used at origin sites without other access. 


\section{Emergency Operations Scenarios}

OCRWM will adhere to the DHS framework and protocols of the National Response Plan in planning, collaboration, and cooperation on emergency management for the Transportation System. OCRWM will conduct on-going evaluations of potential Transportation System vulnerabilities under wide-ranging scenarios and institute appropriate measures to mitigate the consequences of an emergency. Consequences may result from "Acts of God," accidents, mechanical failures, sabotage, or interference. Irrespective of the causative event, situations will be examined where a shipment is stopped but not damaged, or stopped and damaged.

For purposes of discussion, the Transportation System Concept of Operations analyzes four hypothetical events that could occur during an otherwise routine shipment. These four hypothetical scenarios are location independent, rather than site specific. During any transportation incident, the Transportation Operations Center is the primary command and control center for all communications in accordance with the Federal and OCRWM activities at origin sites, on short-line or main-line railroads, or public highways throughout the United States. Below is a list of possible emergency situations and responses. For on-site incident response, OCRWM will follow the Nuclear/ Radiological Incident Annex of the National Response Plan.

\section{(1) Weather}

Situation - Reports indicate a major winter storm is expected within 24 hours along the path of a shipment. A severe storm is expected to impede rail or truck operations.

Response - En-route shipments may be rerouted by the Transportation Operations Center in consultation with carrier dispatchers. Depending on the storm proximity, a train may be held temporarily at the origin site or directed to a marshaling yard for safety, while trucks are directed to secure layover areas. The Transportation Operations Center coordinates with affected States and Tribes, and with the DOE Emergency Transportation Operations Center to arrange contingency plans and implement precautionary measures. The Transportation Operations Center monitors storm conditions (such as NWS alerts) to adjust routing and to issue instructions for resuming shipments. After conditions improve, the Transportation Operations Center authorizes the carriers to resume normal transport.

\section{(2) Minor Train or Truck Malfunction}

Situation - In a remote area, a minor malfunction on a transport vehicle is impairing, though not arresting, shipment (e.g., one flat tire on a truck or a minor defect on a rail car). The shipment is on a rail line or highway within 50 miles of a suitable repair station.

Response - TSF personnel escorting the shipment notify the Transportation Operations Center immediately to report the equipment malfunction, modify transportation plans and schedules, receive authorization to continue at a slower pace, and request advance notice of required repairs be sent to the repair station. The Transportation Operations Center coordinates with the commercial carrier dispatch center to direct the train or truck to the nearest approved repair station. The Transportation Operations Center notifies State and 
Tribal government authorities and requests their assistance in monitoring the progress of the shipment. The Transportation Operations Center coordinates with the DOE Emergency Reponses Center to report on the location and seriousness of the situation and to schedule deployment of security or emergency reinforcements, if required. The Transportation Operations Center communicates repair preparations to the shipment TSF personnel.

At the repair station, TSF personnel secure the shipment while repairs are performed and keep the Transportation Operations Center informed of repair progress. Carrier dispatch centers are directed to modify transport schedules as repairs are completed, and the Transportation Operations Center evaluates the impact of the delay on Transportation System and Repository operations.

\section{(3) Major Accident}

Situation - There is a DOE train derailment, incapacitating the TSF and train crew. The Transportation Operations Center cannot reach the locomotive engineer or on-board TSF.

Response - In carrying out the emergency response and security plan, the Transportation Operations Center alerts the DOE Emergency Response Center immediately of the accident. The Transportation Operations Center notifies State and Tribal emergency response authorities and deploys the DOE Radiological Assistance Program (RAP), Nuclear Emergency Support Team (NEST), and security teams, as requested by local or State/Tribal law enforcement. The Transportation Operations Center maintains communications with the rail carrier's operations center to provide information about the shipment and assist as requested. DOE RAP and security teams coordinate with the appointed local Incident Commander to secure the scene of the accident, aid in recovery of personnel and civilians, test for any potential radioactive release, and assist in recovery operations. The Transportation Operations Center coordinates public information releases; and, in conjunction with rail carrier and the local jurisdiction, evaluates accident impacts on transportation. After all persons are accounted for, the carrier begins cask, equipment, and hazardous material ("hazmat") recovery. DOE teams coordinate with the carrier for recovery and security operations on casks, in evaluating whether to remove the casks to a marshalling yard, and in arranging for further transportation.

\section{(4) Security Incident}

Situation - Protestors attempt to stop a shipment by blocking train tracks.

Response - TSF personnel notify the Transportation Operations Center, which in turn notifies the DOE Emergency Response Center, rail dispatchers, and State and Tribal authorities about the security incident. The Transportation Operations Center implements TOP security instructions, coordinates with railroad security and local law enforcement for the peaceful removal of protestors. The Transportation Operations Center monitors events, evaluates the impact of the protest, and determines whether the shipment may continue at other points along the shipment route. In coordination with the TSF and on-site response and law enforcement, the Transportation Operations Center may request DOE Emergency 
Response security intervention to move the shipment to a safe haven until another route and schedule can be established. The TSF reports to the Transportation Operations Center when it appears the protest has ended and the rail shipment can safely resume. The Transportation Operations Center issues subsequent instructions to the carrier. 


\section{Appendix A}

TRANSPORTATION SYSTEM REFERENCES

\begin{tabular}{|c|c|}
\hline Reference & Brief Description \\
\hline \multicolumn{2}{|r|}{ UNITED STATES POLICY } \\
\hline $\begin{array}{l}\text { Nuclear Waste Policy } \\
\operatorname{Act}(\boldsymbol{N W P A})\end{array}$ & $\begin{array}{l}\text { Requires the U.S. Department of Energy to: } \\
\text { - establish a program to dispose of SNF and HLW } \\
\text { - execute contracts with commercial nuclear utilities to fund the } \\
\text { disposal of SNF and HLW } \\
\text { - provide packaging (casks) for waste certified by NRC under } 10 \\
\text { CFR } 71 \\
\text { - prenotify states of shipments according to } 10 \text { CFR } 73 \\
\text { - fund training of first responders along shipment routes } \\
\text { - contract private industry for transportation to the fullest extent } \\
\text { possible. }\end{array}$ \\
\hline $\begin{array}{l}\text { National } \\
\text { Environmental Policy } \\
\text { Act }\end{array}$ & $\begin{array}{l}\text { Requires completion of an Environmental Impact Statement (EIS) } \\
\text { for major Federal projects and acquisitions. }\end{array}$ \\
\hline $\begin{array}{l}\text { Standard Contract } \\
\text { (10 CFR 961) }\end{array}$ & $\begin{array}{l}\text { Requires DOE to supply casks "suitable-for-use" to } 125 \text { origin } \\
\text { sites at } 77 \text { geographic sites located in } 39 \text { states comprising no } \\
\text { fewer than } 21 \text { different types of commercial spent nuclear fuel. }\end{array}$ \\
\hline \multicolumn{2}{|r|}{ FEDERAL REGULATIONS } \\
\hline $\begin{array}{l}\text { Department of } \\
\text { Transportation (49 } \\
\text { CFR) }\end{array}$ & $\begin{array}{l}\text { Regulates: } \\
\text { - packaging of hazardous materials } \\
\text { - transportation of hazardous materials } \\
\text { - Requires a transportation security plan for hazardous material } \\
\text { shipments. }\end{array}$ \\
\hline $\begin{array}{l}\text { Nuclear Regulatory } \\
\text { Commission } \\
\text { (10 CFR) }\end{array}$ & $\begin{array}{l}\text { Regulates: } \\
\text { - design and certification of packaging to prevent breach in } \\
\text { severe accidents } \\
\text { - pre-shipment notification to states } \\
\text { - in-transit security. }\end{array}$ \\
\hline $\begin{array}{l}\text { DOE } 10 \text { CFR } 830 \text { and } \\
10 \text { CFR } 835\end{array}$ & $\begin{array}{l}\text { Regulation of DOE nuclear facilities } \\
\text { - specifies QA requirements for nuclear application of Systems } \\
\text { Structures and Components } \\
\text { - worker safety in nuclear facilities }\end{array}$ \\
\hline $\begin{array}{l}\text { Environmental } \\
\text { Protection Agency } \\
\text { (EPA) }\end{array}$ & Regulates repository design long-term environmental releases. \\
\hline $\begin{array}{l}\text { Department of } \\
\text { Homeland Security } \\
\text { (DHS) }\end{array}$ & $\begin{array}{l}\text { Requires adherence to the National Response Plan and its } \\
\text { corresponding Nuclear/Radiological Incident Annex. }\end{array}$ \\
\hline
\end{tabular}




\begin{tabular}{|c|c|}
\hline Reference & Brief Description \\
\hline \multicolumn{2}{|r|}{ DOE ORDERS } \\
\hline DOE Order 151.1B & Comprehensive Emergency Management \\
\hline DOE Order 200.1 & Information Management Program \\
\hline DOE Order 205.1 & Cyber Security Management Program \\
\hline DOE Order 221.1 & $\begin{array}{l}\text { Reporting Fraud, Waste, and Abuse to the Office of Inspector } \\
\text { General }\end{array}$ \\
\hline DOE Order $460.2 A$ & $\begin{array}{l}\text { Requires DOE to meet applicable NRC packaging and DOT } \\
\text { transportation of hazardous materials regulations. }\end{array}$ \\
\hline DOE Order 225.1 & Accident Investigations \\
\hline DOE Order 231.1 & Occurrence Reporting \\
\hline DOE Order 252.1 & Technical Standards \\
\hline DOE Order $412.1 A$ & Work Authorization System \\
\hline DOE Order 413.3 & Management Control and Project Execution \\
\hline DOE Order $414.1 B$ & Quality Assurance \\
\hline DOE Order 420.1A & Facility Safety \\
\hline DOE Order 433.1 & Maintenance Management Program for DOE Nuclear Facilities \\
\hline DOE Order 435.1 & Radioactive Waste Management \\
\hline DOE Order 450.1 & Environmental Protection Program \\
\hline DOE Order $460.1 B$ & Packaging and Transportation Safety \\
\hline DOE Order 460.2A & $\begin{array}{l}\text { Departmental Materials Transportation and Packaging } \\
\text { Management }\end{array}$ \\
\hline DOE Order 470.1 & Safeguards and Security Program \\
\hline DOE Order $470.2 B$ & Independent Oversight and Performance Assurance Program \\
\hline DOE Order $471.1 A$ & $\begin{array}{l}\text { Identification and Protection of Unclassified Controlled Nuclear } \\
\text { Information }\end{array}$ \\
\hline DOE Order 474.1A & Control and Accountability of Nuclear Materials \\
\hline DOE Order 5400.5 & Radiation Protection of the Public and the Environment \\
\hline DOE Order 5480.19 & Conduct of Operations Requirements for DOE Facilities \\
\hline DOE Order 5480.4 & $\begin{array}{l}\text { Environmental Protection, Safety, and Health Protection } \\
\text { Standards }\end{array}$ \\
\hline \multicolumn{2}{|r|}{ OCRWM PROGRAM REQUIREMENTS } \\
\hline $\begin{array}{l}\text { Civilian Radioactive } \\
\text { Waste System } \\
\text { Requirements } \\
\text { Document (CRD) }\end{array}$ & $\begin{array}{l}\text { Waste transport capability coinciding with Repository operations. } \\
\text { Transport } 70,000 \text { metric tons of materials in accordance with the } \\
\text { rates provided in the CRD. } \\
\text { Use private sector resources to the maximum extent. } \\
\text { Transport single-purpose, canister, transport/storage, HLW, and } \\
\text { specialty casks. } \\
\text { Design, acquisition, fabrication, operation, and maintenance of } \\
\text { Transportation System assets according to codes and standards } \\
\text { Design of Transportation System facilities according to National } \\
\text { Standards and applicable regulations, including appropriate } \\
\text { sections of DOE HDBK-1132-99, "Design Considerations." } \\
\text { Personnel support and vendor services under FAR and QA } \\
\text { requirements. }\end{array}$ \\
\hline
\end{tabular}




\begin{tabular}{|l|l|}
\hline \multicolumn{1}{|c|}{ Reference } & \multicolumn{1}{c|}{ Brief Description } \\
\hline \multicolumn{2}{|c|}{ OCRWM TRANSPORTATION SYSTEM REQIUREMENTS } \\
\hline $\begin{array}{l}\text { Transportation System } \\
\text { Concept of Operations }\end{array}$ & $\begin{array}{l}\text { Core document presenting system-wide description of the } \\
\text { OCRWM Transportation System. }\end{array}$ \\
\hline $\begin{array}{l}\text { Transportation System } \\
\text { Requirements } \\
\text { Document (TSRD) }\end{array}$ & $\begin{array}{l}\text { Transportation system requirements consistent with and derived } \\
\text { from the Transportation System Concept of Operations. }\end{array}$ \\
\hline $\begin{array}{l}\text { Transportation System } \\
\text { Operations } \\
\text { Implementation Plan } \\
\text { (TSOIP) }\end{array}$ & $\begin{array}{l}\text { Documents decisions, processes, and inter-dependencies of the } \\
\text { Transportation System. }\end{array}$ \\
\hline \multicolumn{1}{|c|}{ OCRWM TRANSPORTATION SYSTEM OPERATIONAL DOCUMENTS } \\
(TO BE DEVELOPED)
\end{tabular}




\section{Appendix B}

\section{Acronyms}

$\begin{array}{ll}\text { AIAA } & \text { American Institute of Aeronautics and Astronautics } \\ \text { ANSI } & \text { American National Standards Institute } \\ \text { CFR } & \text { Code of Federal Regulations } \\ \text { COG } & \text { Continuity of Government } \\ \text { COOP } & \text { Continuity of Operations } \\ \text { CRD } & \text { Civilian Radioactive Waste Management System (CRWMS) Requirements Document } \\ \text { CRWMS } & \text { Civilian Radioactive Waste Management System } \\ \text { CSXT } & \text { CSX Transportation } \\ \text { CVSA } & \text { Commercial Vehicle Safety Alliance } \\ \text { DHS } & \text { Department of Homeland Security } \\ \text { DOE } & \text { Department of Energy } \\ \text { DOT } & \text { Department of Transportation } \\ \text { EIS } & \text { Environmental Impact Statement } \\ \text { EOL } & \text { End of Line Rail Yard } \\ \text { EPA } & \text { Environmental Protection Agency } \\ \text { FAR } & \text { Federal Acquisition Regulations } \\ \text { FBI } & \text { Federal Bureau of Investigation } \\ \text { FDS } & \text { Final Delivery Schedule } \\ \text { FMCSA } & \text { Federal Motor Carrier Safety Administration } \\ \text { FMF } & \text { Fleet Management Facility } \\ \text { FRA } & \text { Federal Railroad Administration } \\ \text { GROA } & \text { Geologic Repository Operating Area } \\ \text { Hazmat } & \text { Hazardous Materials } \\ \text { HHT } & \text { Heavy-Haul Truck } \\ \text { HLW } & \text { High-Level Radioactive Waste } \\ \text { IMT } & \text { Inter-Modal Transfer } \\ \text { LWT } & \text { Legal-Weight Truck } \\ \text { MCEP } & \text { DOE Motor Carrier Evaluation Program } \\ \text { NEST } & \text { Nuclear Emergency Support Team } \\ \text { NNPP } & \text { Naval Nuclear Propulsion Program } \\ \text { NRC } & \text { Nuclear Regulatory Commission } \\ \text { NRL } & \text { Nevada Rail Line } \\ \text { NWPA } & \text { Nuclear Waste Policy Act } \\ \text { NWS } & \text { National Weather Service } \\ \text { OCRWM } & \text { DOE Office of Civilian Radioactive Waste Management } \\ \text { OWT } & \text { Overweight Truck } \\ \text { QA } & \text { Quality Assurance } \\ \text { RAP } & \text { DOE Radiological Assistance Program } \\ \text { SCC } & \text { System Structure and Component } \\ \text { SDD } & \text { System Description Document } \\ \text { SNF } & \text { Spent Nuclear Fuel } \\ \text { TAD } & \text { Transport Aging Disposal } \\ \text { TOM } & \text { Transportation Operations Management model/system } \\ & \end{array}$ 
TOP Transportation Operations Plan

TSF Transportation Security Force

TSRD Transportation System Requirements Document

TSOIP Transportation System Operations Implementation Plan

UP Union Pacific Railroad

USCG United States Coast Guard

WA OCRWM Waste Acceptance Program

YM Yucca Mountain 